Marquette University

e-Publications@Marquette

Biological Sciences Faculty Research and

Publications

Biological Sciences, Department of

4-1-2019

\title{
Population Genetic Structure and Species Delimitation of a Widespread, Neotropical Dwarf Gecko
}

\author{
Brendan J. Pinto \\ Marquette University \\ Guarino R. Colli \\ Universidade de Brasília \\ Timothy E. Higham \\ University of California - Riverside \\ Anthony P. Russell \\ University of Calgary \\ Daniel P. Scantlebury \\ Resonate, Reston, VA
}

See next page for additional authors

Follow this and additional works at: https://epublications.marquette.edu/bio_fac

Part of the Biology Commons

\section{Recommended Citation}

Pinto, Brendan J.; Colli, Guarino R.; Higham, Timothy E.; Russell, Anthony P.; Scantlebury, Daniel P.; Vitt, Laurie J.; and Gamble, Tony, "Population Genetic Structure and Species Delimitation of a Widespread, Neotropical Dwarf Gecko" (2019). Biological Sciences Faculty Research and Publications. 675.

https://epublications.marquette.edu/bio_fac/675 


\section{Authors}

Brendan J. Pinto, Guarino R. Colli, Timothy E. Higham, Anthony P. Russell, Daniel P. Scantlebury, Laurie J. Vitt, and Tony Gamble

This article is available at e-Publications@Marquette: https://epublications.marquette.edu/bio_fac/675 
Marquette University

e-Publications@Marquette

\section{Biology Faculty Research and Publications/College of Arts and Sciences}

This paper is NOT THE PUBLISHED VERSION; but the author's final, peer-reviewed manuscript. The published version may be accessed by following the link in th citation below.

Molecular Phylogenetics and Evolution, Vol. 133 (April 2019): 54-66. DOI. This article is (C) Elsevier and permission has been granted for this version to appear in e-Publications@Marquette. Elsevier does not grant permission for this article to be further copied/distributed or hosted elsewhere without the express permission from Elsevier.

\section{Population genetic structure and species delimitation of a widespread, Neotropical dwarf gecko}

Brendan J. Pinto

Department of Biological Sciences, Marquette University, Milwaukee, WI, USA

Guarino R. Colli

Departamento de Zoologia, Universidade de Brasília, Brasília, DF, Brazil

Timothy E. Higham

Department of Evolution, Ecology, and Organismal Biology, University of California, Riverside, Riverside, CA, USA

Anthony P. Russell

Department of Biological Sciences, University of Calgary, Calgary, AB, Canada

Daniel P. Scantlebury

Resonate, Reston, VA, USA

Laurie J. Vitt 
Sam Noble Museum and Biology Department, University of Oklahoma, Norman, OK, USA

\section{Tony Gamble}

Department of Biological Sciences, Marquette University, Milwaukee, WI, USA

Bell Museum of Natural History, University of Minnesota, Saint Paul, MN, USA

Milwaukee Public Museum, Milwaukee, WI, USA

\section{Abstract}

Amazonia harbors the greatest biological diversity on Earth. One trend that spans Amazonian taxa is that most taxonomic groups either exhibit broad geographic ranges or small restricted ranges. This is likely because many traits that determine a species range size, such as dispersal ability or body size, are autocorrelated. As such, it is rare to find groups that exhibit both large and small ranges. Once identified, however, these groups provide a powerful system for isolating specific traits that influence species distributions. One group of terrestrial vertebrates, gecko lizards, tends to exhibit small geographic ranges. Despite one exception, this applies to the Neotropical dwarf geckos of the genus Gonatodes. This exception, Gonatodes humeralis, has a geographic distribution almost 1,000,000 $\mathrm{km}^{2}$ larger than the combined ranges of its 30 congeners. As the smallest member of its genus and a gecko lizard more generally, $G$. humeralis is an unlikely candidate to be a wide-ranged Amazonian taxon. To test whether or not G. humeralis is one or more species, we generated molecular genetic data using restriction-site associated sequencing (RADseq) and traditional Sanger methods for samples from across its range and conducted a phylogeographic study. We conclude that $G$. humeralis is, in fact, a single species across its contiguous range in South America. Thus, Gonatodes is a unique clade among Neotropical taxa, containing both wide-ranged and range-restricted taxa, which provides empiricists with a powerful model system to correlate complex species traits and distributions. Additionally, we provide evidence to support species-level divergence of the allopatric population from Trinidad and we resurrect the name Gonatodes ferrugineus from synonymy for this population.

\section{Graphical abstract}

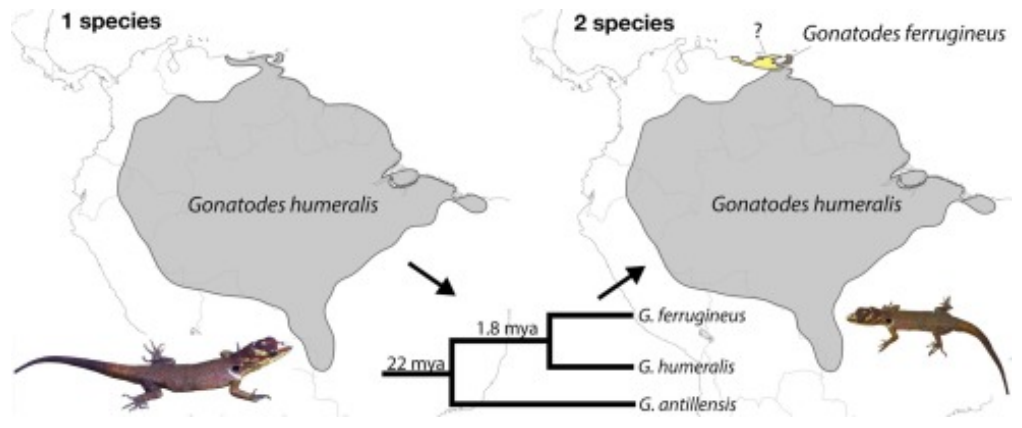

\section{Keywords}

Amazonia, RADseq, Species delimitation, Population genetics, Neotropical phylogeography

\section{Introduction}

The use of genetic data to study variation among populations and delimit species has provided unprecedented insight into the patterns and processes of speciation (Casillas and Barbadilla, 2017, Domingos et al., 2017, Gratton et al., 2015, Harvey et al., 2017, Lemmon et al., 2012, McKay et al., 2013, Nazareno et al., 2017a, Nazareno et al., 2017b, Weir et al., 2015). Genetic data have been particularly useful in the investigation of poorly-studied taxa from Neotropical regions, such as Amazonia (Angulo and Icochea, 2010, Antonelli et al., 
2011). Employing large genetic datasets to Neotropical biogeographic studies can vastly increase their accuracy and resolution relative to previous analyses. Most Neotropical work to date, however, has been conducted using a single type of data (largely mitochondrial data), and has likely led to the oversimplification in our understanding of this biogeographic system (Beheregaray, 2008; Turchetto-Zolet et al., 2013). Thus, in order to elucidate the complex historical scenarios across the Neotropics that have resulted in the immense biodiversity harbored there, studies utilizing larger datasets are needed for a diversity of animal groups.

Several hypotheses have been proposed to explain the historical and spatial patterns of range-limited Amazonian species (see Antonelli et al., 2011, Turchetto-Zolet et al., 2013 for thorough review), nearly all of which depend on the emergence of physical barriers to gene flow that result in allopatric speciation (Haffer, 1969, Haffer, 1997, Endler, 1977, Vanzolini and Williams, 1981, Wallace, 1852). Although there has been considerable debate as to the timing of Amazonian speciation, it now seems clear that cladogenesis has been happening, continually, for tens of millions of years. For instance, many invertebrate, mammal, and bird groups display interspecific divergence between sister species during the Quaternary ( $<2.6$ million years ago [mya]), whereas many amphibians and reptiles exhibit earlier divergence times during the Neogene (>2.6 mya) (Gamble et al., 2008, Antonelli et al., 2011, Fouquet et al., 2015, Turchetto-Zolet et al., 2013). Thus, determining the complex patterns that have generated Amazonian biodiversity may require testing several competing hypotheses and searching for patterns between large- and small-scale studies, across a variety of taxonomic groups. Indeed, and as datasets for Neotropical taxa increase in size, complex historical scenarios have been uncovered that were previously unidentifiable and/or untestable (Alexander et al., 2017, Avila-Pires et al., 2012, Fouquet et al., 2015, Lessa et al., 2003, Nazareno et al., 2017a, Nazareno et al., 2017b, Prates et al., 2016, Werneck et al., 2012).

One trend that molecular genetic data have revealed is that many widely distributed tropical taxa are composed of multiple, often cryptic, species (Funk et al., 2012). These species are usually of smaller body size, with low vagility, and/or those that occupy narrow ecological niches (Camargo et al., 2006, Fouquet et al., 2007b, Wynn and Heyer, 2001). Indeed, even prior to the advent of molecular genetic data, it was predicted that very few widespread nominal taxa in the Neotropics would remain intact upon closer investigation (Lynch, 1979). Subsequently, phylogeographic studies of multiple populations have found that most widespread, nonvolant, vertebrate taxa are in fact 'species-complexes' (i.e. composed of multiple undescribed and/or cryptic species). This pattern extends across many terrestrial vertebrate groups including, but not limited to: anole lizards (D'angiolella et al., 2011, Glor et al., 2001), frogs (Camargo et al., 2006, Caminer et al., 2017, Chek et al., 2001, Fouquet et al., 2007a, Fouquet et al., 2014, Funk et al., 2012, Gehara et al., 2014, Guayasamin et al., 2017, Wynn and Heyer, 2001), gecko lizards (Bergmann and Russell, 2007, Gamble et al., 2011a, Geurgas and Rodrigues, 2010, Kronauer et al., 2005), salamanders (Hervas et al., 2016), toads (Fouquet et al., 2007a, Funk et al., 2012, Murphy et al., 2017b), and other herpetofauna (Nunes et al., 2012, De Oliveira et al., 2016). Furthermore, identifying concordant patterns in species' ranges is an important step in the testing of complex biogeographical scenarios that underpin the origins of biodiversity (Clarke et al., 2017a, Clarke et al., 2017b, Costello et al., 2013, Da Silva and Patton, 1993, Díaz-Nieto et al., 2016, Ditchfield, 2000, Gazoni et al., 2018, Gehara et al., 2014, Miralles and Carranza, 2010, Stroud et al., 2017, Turchetto-Zolet et al., 2013).

Whereas many widespread Neotropical taxa appear to be composed of multiple, undescribed species, there are exceptions to this pattern and widely distributed Neotropical taxa do exist. However, these widespread taxa are less frequent than once thought and are typically species that exhibit traits that facilitate high vagility (e.g. being volant, having a large body size, and/or occupying broad ecological niches). Some notable examples of these widespread taxa include: the Amazon Tree Boa (Corallus hortulanus), Andersen's Fruit-eating Bat (Artibeus anderseni), the Bushmaster (Lachesis muta), capybaras (Hydrochoerus hydrochaeris), jaguars (Panthera onca), the Green Anaconda (Eunectes murinus), the Green Iguana(Iguana iguana), and the Lesser Treefrog (Dendropsophus minutus) (Colston et al., 2013, Ditchfield, 2000, Eizirik et al., 2001, Gehara et al., 2014, Zamudio and Greene, 1997). These examples suggest that range size and abundance of Neotropical 
species are likely attributable to intrinsic factors such as body size, dispersal ability, and niche breadth, among other traits that have a strong phylogenetic component (Dexter and Chave, 2016, Meiri et al., 2017, Wynn and Heyer, 2001). Thus, some clades are composed mostly of wide-ranging species (large and volant animals), while others are composed mainly of range-limited species (small and dispersal-limited animals). Studying differences in ecological traits and range distribution among these taxa can provide important insights into the patterns and processes responsible for Neotropical biodiversity. However, it is difficult to deduce the relative contribution of individual traits to range size disparities between species, because many traits are autocorrelated at the macroevolutionary scale (Beck and Kitching, 2007, Dexter and Chave, 2016, Hurlbert and White, 2007). Investigating clades that include both geographically widespread and restricted species may provide important insights into how phenotypic differences can influence species distributions (Gehara et al., 2014).

In line with these observations, most Neotropical lizard species have small distributions. However, there are a few notable exceptions, such as the dwarf gecko, Gonatodes humeralis, the geographic distribution of which $\left(\sim 7,600,000 \mathrm{~km}^{2}\right)$ is larger than that of all its congeners combined, by nearly $1,000,000 \mathrm{~km}^{2}\left(\sim 6,700,000 \mathrm{~km}^{2}\right)$ (Roll et al., 2017). Gonatodes humeralis occurs across Amazonia and the Guiana Shield, as well as in forested enclaves and gallery forests in the adjacent Cerrado and Caatinga biomes, and on the island of Trinidad (AvilaPires, 1995, Murphy, 1997, Ribeiro-Júnior, 2015, Roberto et al., 2014, Vanzolini, 1955). Overall, its current distribution occupies a geographic area marginally smaller than that of the continental United States and overlaps with 13 currently described congeneric species (Supplemental Fig. 1). Gonatodes humeralis also exhibits a broad niche breadth, occurring in a variety of habitat types including: primary and secondary forest, riparian forest, gallery forest, forest edges, bamboo forest, and human dwellings (Carvalho et al., 2008, Dixon and Soini, 1986, Higham et al., 2017, Hoogmoed, 1973, Vanzolini and Williams, 1981, Vitt and Zani, 1996, Vitt et al., 1997, Vitt et al., 2000). Its massive distribution and extensive niche breadth contrast with those of its congeners, most of which occupy specialized niches with small, distributions in Central and South America and several islands of the Lesser Antilles (Supplemental Fig. 1). In the context of recent discoveries suggesting that widespread Neotropical taxa are uncommon, the diminutive G. humeralis (maximum $41.5 \mathrm{~mm}$ snout-vent length; Avila-Pires, 1995) is an unlikely candidate for being a single species. However, if G. humeralis is, in fact, one widespread species, then Gonatodes harbors both widespread and geographically restricted taxa, providing a powerful model system for identifying traits that may influence species distributions.

Previous investigations on $G$. humeralis have revealed evidence for genetic, ecological, and morphological variation between populations across its range (Avila-Pires, 1995, Avila-Pires et al., 2012, Rivero-Blanco, 1979 , Vitt et al., 1997), and early hypotheses suggested that populations should exhibit relatively shallow divergence times, within the Pleistocene (Vanzolini and Williams, 1981, Vitt et al., 1997). Supporting this, the first multi-locus phylogenetic analysis of Gonatodes revealed that G. humeralis samples from eastern and western Amazonia likely shared a common ancestor in the late Pliocene or early/mid Pleistocene, approximately 1.9 (1.1-2.7) mya (Gamble et al., 2008). Later, the most comprehensive phylogeographic analysis to date investigated the history of $G$. humeralis populations in eastern Amazonia using two mitochondrial markers (Cytb \& 16S) from 56 individuals (Avila-Pires et al., 2012). The authors found little phylogenetic resolution among sampled populations and no evidence that Amazonian rivers (namely, the Amazon and Tocantins) have acted as isolating mechanisms between sampled populations in eastern Amazonia. The authors concluded that rangewide sampling and the addition of nuclear markers would be necessary to obtain sufficient resolution of any phylogeographic hypothesis relating to this species.

We herein investigate the geographically widespread gecko, G. humeralis, across its range in northern South America and Trinidad. Specifically, we test two alternative hypotheses: (i) if G. humeralis is typical of most small, non-volant Neotropical vertebrates, we expect to uncover a species-complex composed of multiple cryptic, or morphologically similar, species; (ii) conversely, if G. humeralis is an atypical taxon, then we expect it to be a single, widespread species across its contiguous Amazonian range, and potentially also on the island of Trinidad. To test this, we generated restriction-site associated DNA sequencing (RADseq) data, and a multi-locus Sanger- 
sequenced dataset using traditionally informative nuclear and mitochondrial markers. We began by investigating the population genetic structure of $G$. humeralis across its range, then reconstructed the relationships of those alleles between populations, and used these relationships to generate specific species delimitation hypotheses for further testing. Indeed, we predicted that $G$. humeraliswould consist of multiple, cryptic species with distributions comparable in size to those of other species of Gonatodes. However, we found that $G$. humeralis is a single, widespread species across Amazonia, whereas the population on the island of Trinidad appears to be highly divergent and independently-evolving. We discuss these results in a comparative context with other Neotropical species and posit that this genus of geckos (Gonatodes) may yield unprecedented insights into the origins and maintenance of Neotropical biodiversity.

\section{Materials and methods}

\subsection{Sampling}

We sampled 31 individuals of $G$. humeralis from 13 localities across its range (Fig. 1). Three individuals of $G$. antillensis were included as an outgroup (Russell et al., 2015). We extracted genomic DNA for downstream genetic sequencing from tail clips or liver, using the Qiagen ${ }^{\circledR}$ DNeasy Blood and Tissue extraction kit.

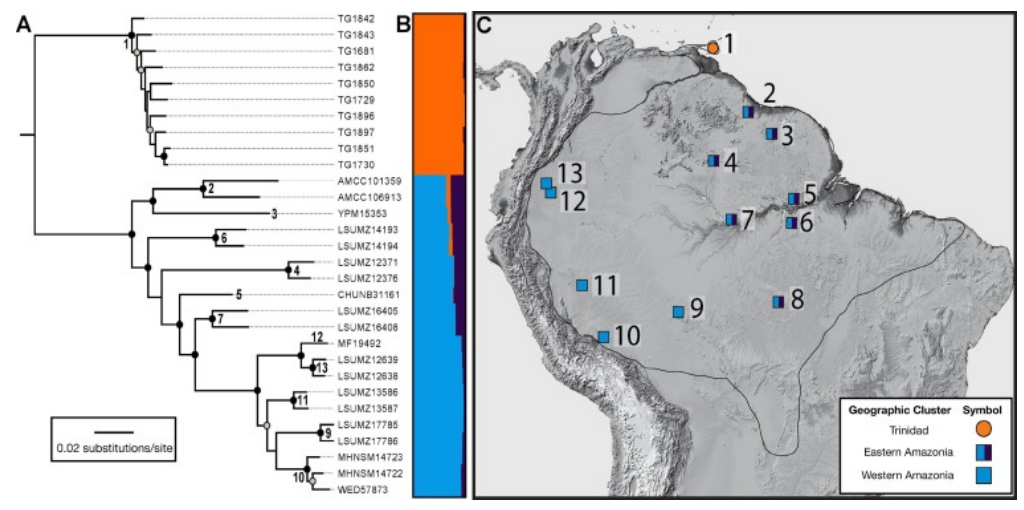

Fig. 1. (A) Maximum-likelihood tree computed using 22,486 unlinked SNPs executed in RAxML, bootstrap values $\geq 70$ reported (bootstrap values of $100=$ black circles, bootstrap values from 70 to $99=$ gray circles). Bolded numbers correlate individual or clade with sampling locality depicted on map. (B) Distruct plot depicting proportions of shared alleles present in the $G$. humeralis lineage determined by STRUCTURE analysis, $\mathrm{K}=3$ (Supplemental Fig. 2). (C) Map indicating sampling localities, within the geographic range of $G$. humeralis, in relation to cluster assignments (Trinidad $=$ circle, west Amazonia $=$ solid square, east Amazonia $=$ patterned square) in relation to their geographic locality (Supplemental Table 1). Further, locality 8 (represented by CHUNB47049) is absent from the RADseq tree in panel A (see Methods).

\subsection{RADseq data}

We generated a reduced-representation genomic dataset for all G. humeralis individuals using restrictionsite associated DNA sequencing(RADseq). RADseq libraries were constructed following a protocol modified from Etter et al. (2011), as described by Gamble et al. (2015). Briefly, genomic DNA was digested using highfidelity Sbfl restriction enzyme (New England Biolabs). We ligated individually barcoded P1 adapters onto the $S b f l$ cut site for each sample. Samples were pooled into multiple libraries, sonicated, and size selected into 200- to 500-basepair (bp) fragments using magnetic beads in a PEG/NaCl buffer (Rohland and Reich, 2012). Libraries were blunt-end-repaired and dA tailed. To each of the pooled libraries, we ligated a P2 adapter containing unique Illumina barcodes. Libraries were amplified using 16 PCR cycles with Phusion high-fidelity DNA polymerase (New England Biolabs), and were size-selected a second time into 250- to $600 \mathrm{bp}$ fragments using magnetic beads in PEG/NaCl buffer. Libraries were sequenced using paired-end 125 bp reads on the Illumina ${ }^{\circledR}$ 
HiSeq2500 at the Institute for Integrative Genome Biology, University of California, Riverside. RADseq data for the 10 individuals from Trinidad were previously published (Gamble et al., 2018).

We trimmed and demultiplexed raw single-end Illumina sequencingreads by their individual-specific barcodes using the process_radtags command in STACKS [v1.23]; (Catchen et al., 2011). After the removal of low-quality reads, restriction site overhangs, and barcodes, the $3^{\prime}$ ends of the $125 \mathrm{bp}$ reads were trimmed to $100 \mathrm{bp}$.

Cleaned reads were imported into the PyRAD pipeline [v3.0.63] for de novo assembly [steps 2-7] (Eaton, 2014). One individual, CHUNB47049, was removed from the RADseq dataset prior to filtering, due to low-quality reads (adjusting our RADseq dataset, $\mathrm{N}=30$ ). This removed locality \#8 (Fig. 1c) from all RADseq data analyses. We assayed various filtering criteria configurations, including varying the minimum read depth per locus from 4 to 12; maximum number of " $\mathrm{N}$ "s per locus from 4 to 6; within- and across-sample clustering threshold from 80 to 98\%; and the minimum number of individuals with sequence data for a locus needed from 10 to 28 . To obtain a dataset with $>10,000$ and $<50,000$-unlinked markers incorporating $\leq 10 \%$ missing data, we set the final filtering criteria for exclusion of any locus with a read depth of less than 8 reads, and missing data ("N" characters) to $\geq 5$. We set the within- and across-sample clustering threshold to $95 \%$ sequence identity, and the minimum number of individuals required for data to be included in a final locus was set to 25 of the 30 individuals. All other PyRAD parameters used default settings. The final dataset consisted of 35,260 informative loci with 67,173 total singlenucleotide polymorphisms (SNPs), 26,486 of which were unlinked (sampling only one SNP per RAD locus). We subsampled and reformatted this final dataset for all downstream RADseq data analyses; further data specifics for each analysis are provided below.

\subsection{Sanger sequence data}

We also produced sequence data from fragments of six molecular markers using Sanger sequencing of PCR amplicons. This consisted of four nuclear genes: microtubule-associated protein $1 \mathrm{~b}-$ exon 5

(MAP1b), recombination-activating gene 1 (RAG1), oocyte-maturation factor MOS (CMOS), and protein tyrosine phosphatase nonreceptor type 12 (PTPN12); and two mitochondrial genes: NADH dehydrogenase subunit 2 (ND2) and 16S ribosomal subunit (16S). PCR conditions and primer sequences are described elsewhere: MAP1b (Werneck et al., 2012), RAG1, CMOS, PTPN12 (Gamble et al., 2011b), ND2 (Jackman et al., 2008), and 16S (Gamble et al., 2008). We Sanger-sequenced PCR amplicons using GeneWiz ${ }^{\circledR}$ single-pass sequencing, then assembled and quality-trimmed raw sequences using Geneious ${ }^{\circledR}$ [v9.1.5] (Kearse et al., 2012). GenBankaccession numbers for all sequences are listed in Supplemental Table 1. Sequences were aligned using MUSCLE [V3.8.425] (Edgar, 2004) and alignments refined by eye, if necessary. Models of molecular evolutionwere chosen based on AICc and BIC criteria, computed using MEGA7 (Kumar et al., 2016).

\subsection{Population genetic analyses}

We visualized the population-level genetic diversity within $G$. humeralis sensu lato and estimated the number of genetic populations in Hardy-Weinberg equilibrium present in our RADseq data using STRUCTURE [V2.3.4] (Pritchard et al., 2007). We investigated possible values of $\mathrm{K}$ (where $\mathrm{K}$ is equal to the number of populations of alleles) between 1 and 6 with a subset of the unlinked SNP data, using only the first 16,382 SNPs, for computational efficiency, with the admixture model (starting alpha $=1.0$ ), with correlated allele frequencies (fixed lambda $=1.0$ ), and all other priors set to default. We tested $\mathrm{K}$ values by repeating five independent MCMC chains of 150,000 replicates, each with a $10 \%$ burnin. STRUCTURE output was parsed and visualized using the Evanno method in Structure Harvester (Earl and vonHoldt, 2011, Evanno et al., 2005) and the CLUMPAK server (Kopelman et al., 2015).

To further characterize the population genetic structure of mainland G. humeralis and how this structure might confound our species delimitation methodologies (see Species Delimitation below), we tested for (i) isolation-bydistance (IBD), (ii) deviations from neutral expectations, and (iii) calculated metrics of genetic diversity. (i) We tested for isolation-by-distance (IBD) using Mantel's test (Diniz-Filho et al., 2013, Mantel, 1967). We generated a 
geographic distance matrix from locality information using the Geographic Distance Matrix Generator software (Ersts, 2006) and a pairwise $F_{\text {st }}$ distance matrix for our unlinked SNP $(26,486)$ dataset using Arlequin [v3.5.2.2] (Excoffier and Lischer, 2010). We converted the geographic distance into a Euclidean distance matrix with the quasieuclid function in the ade4 package [v1.7.4] (Dray and Dufour, 2007) in R ( conducted Mantel's test, also using ade4, with the mantel.randtest function, creating 999 randomized permutations to calculate $p$-values. (ii) We tested whether sampled populations deviated from expectations under a neutral model by calculating Tajima's D (Tajima, 1989) and Fu's Fs (u, 1997) statistics for two datasets, our concatenated mitochondrial loci (mtDNA) and RADseq SNPs. Neutrality test statistics for the mitochondrial data were estimated using DNAsp [v5.0]; (Librado and Rozas, 2009) and for genotypic SNP data we used PopGenome [v2.1.6] package (Pfeifer et al., 2014) in R (R Core Team, 2016). (iii) We calculated nucleotide diversity $(\pi)$ and within- and between-group genetic distances for ND2 for all three populations and their sister group, G. antillensis, in DNAsp [v5.0] (Librado and Rozas, 2009) and MEGA7 (Kumar et al., 2016), respectively. In addition, we calculated net between-group distances (Nei and Li, 1979) between G. humeralis clusters, as identified by STRUCTURE, using MEGA7, for 16S and ND2 separately, using uncorrected pdistances (Edwards and Beerli, 2000). Standard error estimates were calculated using 500 bootstrap replicates.

\subsection{Phylogenetic inference}

We estimated the phylogenetic relationships among sampled G. humeralis using maximum-likelihood (ML) and Bayesian methods. To analyze our data in an ML framework, we formatted the 26,486 unlinked RADseq SNPs using the shinyPhrynomics package [v1.3] (Leaché et al., 2015) based in R (R Core Team, 2016). We generated a ML tree using RAxML [HPC-v8.2.9] under a GTR $+\lceil$ model with 1000 rapid bootstrap replicates, using the automatic bootstopping function (Stamatakis, 2014), implemented on the CIPRES cluster (Miller et al., 2010). We corrected for SNP-only data biases by estimating ML branch lengths from SNP-only data using the Stamatakis correction, which focuses on minimizing branch length overestimation due to acquisition bias, as described for use with SNP data by Leaché et al. (2015).

We also produced a rooted mitochondrial gene tree in a Bayesian framework, to compare with the nuclear SNP data tree, using BEAST2 [v2.5.1] under a strict clock (Bouckaert et al., 2014) on the CIPRES cluster (Miller et al., 2010). The concatenated mitochondrial (mtDNA) data (ND2 and 16S) consisted of 34 samples, including three $G$. antillensis, for a total of $1484 \mathrm{bp}$. We used the GTR $+\Gamma$ model and a Yule tree prior with $5 \times 10^{8} \mathrm{MCMC}$ iterations with a $10 \%$ burnin. Bayesian analyses were replicated three times and examined by eye using Tracer [v1.6.1] to ensure convergence. Post-burnin trees from all three runs were combined to estimate final tree parameters using Log Combiner and Tree Annotator, respectively.

Next, we estimated divergence time among G. humeralis populations using the StarBEAST2 [v0.15.1] (Ogilvie et al., 2017) module of BEAST2 (Bouckaert et al., 2014). We used the multi-locus Sanger sequence data, sampling 15 Gonatodes species using a secondary calibration at the root following Higham et al. (2017) and individuals of three G. humeralisphylogeographic clusters identified by STRUCTURE: Trinidad, eastern, and western Amazonia, based on the (see Population Genetic Analyses). The final dataset used in this analysis included seven loci: ACM4, CMOS, mtDNA (ND2 + 16S), PDC (phosducin), PTPN12, RAG1, and RAG2; nuclear loci were phased using DNAsp [v5.0] (Librado and Rozas, 2009, Stephens et al., 2001). Loci used in this analysis were chosen specifically to minimize the amount of missing data per taxon while combining newly generated and previously published sequence data (Supplemental Table 2). Indeed, each locus was provided its own best-fit as calculated in MEGA7 (and has an available model in StarBEAST2), this was HKY $+\Gamma$ for all nuclear loci and GTR $+\Gamma$ for our concatenated mtDNA genes. We used an uncorrelated lognormal clock model, with secondary calibration from a previously published fossil-calibrated phylogenetic reconstruction, to provide a prior on the root age between Gonatodes and its sister clade Lepidoblepharis at approximately $72.5( \pm 7.5)$ mya, with a uniform distribution to reflect confidence intervals (Gamble et al., 2015). 
To corroborate these findings, we utilized the published rate of molecular evolution for the mitochondrial ND2 gene in geckos. We estimated the divergence time between the mainland and Trinidad using $p$-distances assuming a strict molecular clock. We calculated p-distances in MEGA7 (Kumar et al., 2016) and calculated the divergence time according to the previously published rate of molecular evolution for the ND2 locus in geckos, at $0.57 \%$ (per lineage rate) per million years (Macey et al., 1999), i.e. (p-distance/ $2 * 100) * 0.57=$ lineagedivergence in millions of years.

\subsection{Species delimitation}

We assessed whether $G$. humeralis consists of one, two, or three putative species using our phylogenetic and STRUCTURE results to guide assignment of individuals into putative species-level lineages using three species delimitation methods: Poisson Tree Processes (PTP), STACEY, and Bayes Factor Delimitation (BFD).

First, we analyzed species boundaries using our Bayesian mitochondrial gene tree with the single-rate PTP test, using the PTP web service (http://mptp.h-its.org/\#/tree), with the p-value set at 0.001 (Kapli et al., 2017).

Second, we used STACEY [v1.2.4] (Jones, 2017) with our Sanger sequenced dataset (CMOS, MAP1b, PTPN12, RAG1, and mtDNA), including $G$. antillensis and $G$. concinnatus as outgroups. In accordance with program documentation and additional specifications outlined by Barley et al. (2018), we provided an exponential distribution with a mean of 0.1 for the "popPriorScale" parameter, a lognormal distribution with a mean of 5 and a standard deviation of 2 to the "bdcGrowthRate" prior, and the "collapseWeight" was provided a uniform distribution with the lower and upper bounds set at 0 and 1, respectively (Barley et al., 2018). In addition, each gene partition was provided the best-fit model of molecular evolution used by the STACEY package (CMOS and PTPN12 - JC; MAP1b and RAG1 - HKY; mtDNA - TN93), an independent strict molecular clock, with rate priors calculated from a log-normal distribution that were given a mean of 0 and standard deviation of 1 (Barley et al., 2018). We ran three independent chains of $5.0 \times 10^{7}$ MCMC repetitions, sampling every 5000 trees, and compared trace files using Tracer [v1.7] (Rambaut et al., 2018). We combined tree files using LogCombiner, visualized them using DensiTree, and analyzed the resulting 30,000 trees using the SpeciesDelimitationAnalyzer [v1.8], herein STACEY and SpeciesDelimitationAnalyzer are referred to as SSDA. We used a burnin of 5000 trees and a collapse-height of 0.0001 to calculate our final species delimitation posterior.

Third, we compared two alternative species models, the 2-taxon (PTP: Trinidad/mainland) and 3-taxon models (SSDA: Trinidad/east Amazonia/west Amazonia), using BFD with the RADseq SNP dataset (Leaché et al., 2014). BFD utilizes the path-sampling analysis of the SNAPP package (Bryant et al., 2012) in BEAST2 (Bouckaert et al., 2014) to infer species boundaries directly from biallelic SNP data by comparing the likelihood of two differing species models using Bayes factors (Leaché et al., 2014). We used 48 path sampler steps with 100,000 MCMC repetitions and a $10 \%$ burnin to sample from 500,000 MCMC SNAPP replications. We systematically compared models using Bayes factors, calculated using $\mathrm{BF}=2 *(\mid$ model $1|-|$ model $2 \mid)$, where the "model" represents the marginal-likelihood estimate from the specific model being compared against (Ogilvie and Leaché, 2016). We ensured that each model was better than random by estimating the marginal-likelihood for a 3-taxon model, where all individuals were randomly assigned to a "species" to ascertain that both models were better than an unrealistic "null" model (Burbrink et al., 2011).

Lastly, we conducted topology tests to assess whether we could reject the hypothesis that eastern and western Amazonia were reciprocally monophyletic, potentially providing support for the hypothesis that each cluster is a distinct lineage. We constructed two sets of ML trees using RAxML [HPC2-v8.2.10] under a GTR $+\lceil$ model, with RAxML's automatic bootstopping function (Stamatakis, 2014), also implemented on the CIPRES cluster (Miller et al., 2010) for our RADseq SNP dataset (described above) and for our mtDNA (ND2 and 16S). We constructed an unconstrained tree and a tree for which we enforced a reciprocal monophyletic constraint between eastern and western Amazonia. We conducted topology tests between both trees using the Shimodaira-Hasegawa (SH) test (Shimodaira and Hasegawa, 1999) and Shimodaira's Approximately Unbiased (AU) test (Shimodaira, 2002) in a 
likelihood framework under a GTR model with an estimated rate matrix. Topology tests were conducted in Phylogenetic Analysis Using Parsimony (PAUP*) [v 4.0a157] (Swofford, 2002). We calculated significance using 10,000 RELL bootstrap replications.

\section{Results}

\subsection{Population genetic STRUCTURE}

The best-fit model for the STRUCTURE analysis was for three populations of alleles in Hardy-Weinberg equilibrium $(\mathrm{K}=3)$. These STRUCTURE results in light of phylogenetic reconstruction indicated that, Trinidadian individuals are distinct from the mainland, but most alleles are shared across the mainland. However, there is a small proportion of unique alleles specific to eastern Amazonia (Fig. 1, Supplemental Fig. 2), which could be due to a variety of factors (see Discussion). Alleles belonging to the allopatric Trinidad population were distinct from those of the mainland ('orange') (Fig. 1, Table 1), so we excluded Trinidadian individuals from certain subsequent population-level analyses (i.e. neutrality tests and testing for IBD). Further investigation into the population structure and demographic history of mainland G. humeralis involved three analyses. (i) we tested against a neutral model of molecular evolution for evidence of rapid population expansion across the mainland, and we looked for concordance between two test statistics, Tajima's D and Fu's Fs. Neither test showed a deviation from neutrality for either the mitochondrial or RADseq SNP data (Table 3). (ii) we tested for the presence of IBD across the mainland using Mantel's test (Table 1, Table 2) by correlaing a matrix of pairwise genetic distances and a matrix of geographic distances. This analysis revealed strong evidence for IBD across mainland South America (Table $2, R^{2}=0.637$, $p$-value $=0.001$ ). (iii) we estimated within-population genetic distance ( $p$-distance) and within-population nucleotide diversity $(\pi)$ for each population and the outgroup, G. antillensis, for mtDNA (Supplemental Table 3). These measurements showed that G. humeralisfrom eastern Amazonia exhibits more genetic diversity than western populations, and that Trinidadian $G$. humeralis display very little genetic diversity overall when compared to mainland populations.

Table 1. Pairwise uncorrected net between-group mean p-distances for mitochondrial data: ND2 (below diagonal) and 16S (above diagonal). Distances and confidence intervals calculated via 500 bootstrap replicates using MEGA7 software (Kumar et al., 2016).

\begin{tabular}{|l|l|l|l|l|}
\hline Population & East & West & Trinidad & Outgroup \\
\hline East & 0 & $0.012 \pm 0.003$ & $0.02 \pm 0.006$ & $0.25 \pm 0.021$ \\
\hline West & $0.05 \pm 0.01$ & 0 & $0.023 \pm 0.006$ & $0.249 \pm 0.021$ \\
\hline Trinidad & $0.1 \pm 0.01$ & $0.09 \pm 0.01$ & 0 & $0.253 \pm 0.021$ \\
\hline Outgroup & $0.56 \pm 0.01$ & $0.56 \pm 0.02$ & $0.56 \pm 0.01$ & 0 \\
\hline
\end{tabular}

Table 2. Summary of test results sectioned by phylogeographic cluster. Mantel test reports indicate within and across cluster presence of isolation by distance ${ }^{* * *}$ indicates significant correlation). Test statistics reported within and across clusters indicate divergence from a neutral model (no tests reported as being significant); "mtDNA" tests were conducted in DNAsp [v5.0]; (Librado and Rozas, 2009), whereas "RADseq" tests were conducted in R ( R Core Team, 2016) using the PopGenome [v2.1.6] package (Pfeifer et al., 2014). Species delimitation method results are reported by geographic cluster; $(\checkmark)$ indicates the delimitation of that cluster as a separate species via the method listed, whereas (-) indicates a failure to delimit a geographic cluster as a species (PTP - Poisson Tree Processes; SSDA - STACEY and SpeciesDelimitationAnalyzer; BFD - Bayes Factor Delimitation).

\begin{tabular}{|l|l|l|l|l|l|l|l|l|}
\hline $\begin{array}{l}\text { Geographic } \\
\text { Cluster }\end{array}$ & $\begin{array}{l}\text { Mantel's } \\
\text { Test }\end{array}$ & & $\begin{array}{l}\text { Neutrality } \\
\text { Test }\end{array}$ & & $\begin{array}{l}\text { Species } \\
\text { Relimitation }\end{array}$ & & SSDA & BFD \\
\hline R-square & $\begin{array}{l}\text { P- } \\
\text { value }\end{array}$ & Data & $\begin{array}{l}\text { Tajima's } \\
\text { D }\end{array}$ & Fu's Fs & PTP & & \\
\hline Trinidad & -0.504 & 0.794 & mtDNA & -0.036 & -1.910 & $\checkmark$ & $\checkmark$ & $\checkmark$ \\
\hline & & & RADseq & -1.439 & -0.905 & & & \\
\hline
\end{tabular}




\begin{tabular}{|l|l|l|l|l|l|l|l|l|}
\hline Mainland & 0.637 & $0.001^{* *}$ & mtDNA & -0.942 & 0.579 & $\checkmark$ & $\checkmark$ & $\checkmark$ \\
\hline & & & RADseq & -1.972 & -0.978 & & & \\
\hline Mainland (East) & 0.045 & 0.386 & mtDNA & -0.796 & -0.241 & - & $\checkmark$ & $\checkmark$ \\
\hline & & & RADseq & -1.314 & 1.192 & & & \\
\hline Mainland (West) & 0.594 & 0.162 & mtDNA & 0.148 & 4.142 & - & $\checkmark$ & $\checkmark$ \\
\hline & & & RADseq & -0.469 & 0.143 & & & \\
\hline
\end{tabular}

Table 3. Species delimitation models compared using Bayes factors with BFD, ranked by marginal likelihood estimate (MLE). Bayes factors reported as pairwise comparisons of a randomized 3-taxon model versus being listed by each model [Bayes factor $=2 *(\mid$ MLE model $1|-|$ MLE model $2 \mid)$ ]. Pairwise In(BF) calculations select both the 2-taxon (10.4) and 3-taxon (10.8) models as being significantly better than random species assignments using the Kass and Raftery (1995) scale; where $\ln (\mathrm{BF}) \geq 5$ there is strong support for the model with the higher MLE. Pairwise comparison between 2-taxon and 3-taxon models results in a $\ln (B F)=9.5$, providing decisive support in favor of the 3-taxon model.

\begin{tabular}{|l|l|l|l|}
\hline Taxon Statement Model Tested & MLE & Rank & Bayes Factor \\
\hline Randomized 3-taxon Statement & $|-104081.08|$ & 3 & - \\
\hline 2-taxa (Trinidad \& Mainland) & $|-87439.54|$ & 2 & 16645.86 \\
\hline 3-taxa (Trinidad, East, \& West) & $|-80789.26|$ & 1 & 6645.96 \\
\hline
\end{tabular}

\subsection{Phylogenetic inference}

Phylogenetic relationships at well-resolved nodes was largely concordant across the methodologies and data sets used (Fig. 1, Fig. 2b). ML and Bayesian methods recovered reciprocally monophyletic Trinidadian and mainland populations using RADseq and Sanger sequenced mitochondrial and nuclear datasets (Fig. 1 , Fig. 2, Supplemental Figs. 3, 4, and 5). Indeed, overall relationships among mainland populations were concordant at well-supported nodes, with a broader Amazonian clade containing a nested monophyletic group from western Amazonia. Between-group mean genetic distances among $G$. humeralisphylogeographic clusters ranged from 0.05-0.1 and 0.012-0.023 for ND2 and 16S, respectively (Table 1). Divergence times between Trinidad and mainland G. humeralis lineages were estimated to occur in the early Pleistocene: 1.89 mya [0.90-2.42, 95\% HPD] (Fig. 2; Supplemental Fig. 5) using a secondary calibration and 2.7 mya [2.45-2.91] assuming a strict clock using the published ND2 rate calibration in geckos [p-distance $=0.094 \pm 0.008$ ]. There was more consensus on the estimated divergence time between populations in eastern and western Amazonia, where mean values varied from 1.59 [0.13-3.0] (calibration) to 1.60 [1.48-1.71] mya (ND2 rate) [p-distance $=0.056 \pm 0.004$ ].
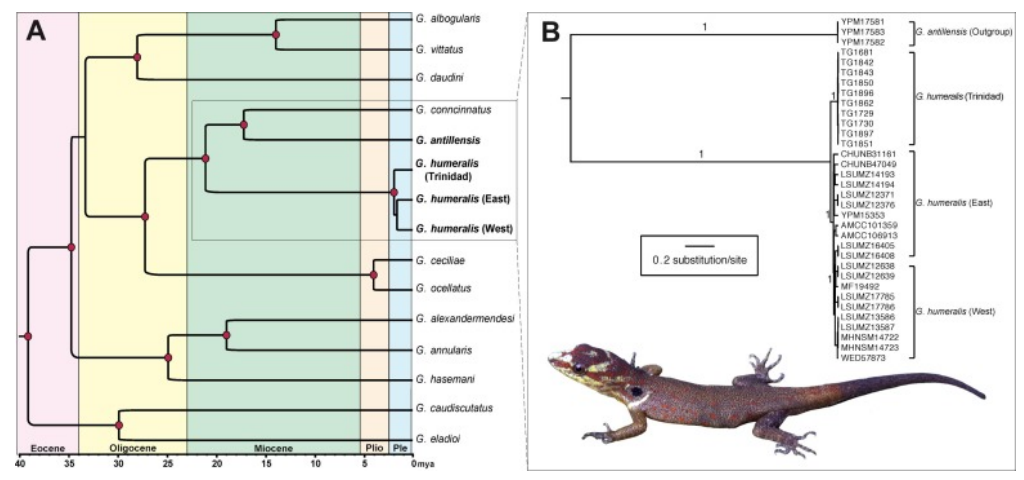

Fig. 2. Phylogenetic inference using two Bayesian inference methods. (A) Time-calibrated StarBEAST2 multi-locus phylogenetic inference (trimmed from Supplemental Fig. 5). Red dots at nodes indicate nodal support $\geq 0.95$ posterior probability. Scale in millions of years before present (mya) and geological era indicated via shaded boxes (Plio = Pliocene, $\mathrm{Ple}=$ Pleistocene). (B) Mitochondrial gene tree generated with ND2 and 16S on zoomed in region from part A. Numeric values indicate posterior probability support for the adjacent node. Shallow, haplotype-level support values are removed for clarity. Precise posterior support for all nodes, however, are 
reported in cladogram format in Supplemental Fig. 3. (For interpretation of the references to colour in this figure legend, the reader is referred to the web version of this article.)

\subsection{Species delimitation}

We utilized three well-documented statistical species delimitation methods (PTP, STACEY, BFD) to examine species limits between the three phylogeographic clusters previously identified by STRUCTURE (Fig. 1). Analysis of our mtDNA gene tree using PTP revealed significant species-level divergence between Trinidad and mainland clades ( $p$-value $=0.001$ ), but not between eastern and western Amazonia (Supplemental Fig. 3 ). Analysis of the multi-locus Sanger sequenced dataset with STACEY and SpeciesDA (SSDA) supported the Trinidad and mainland South American clades as being distinct, species-level lineages ( $p p=0.999)$ (Table

2, Supplemental Fig. 4). SSDA analyses also yielded an additional species delimitation hypothesis within the mainland, identifying populations from eastern Amazonia and western Amazonia as separate species (Table 2, Supplemental Fig. 6). We used BFD to compare the two-species (Trinidad + mainland) model, favored by PTP, and the three-species (Trinidad + eastern Amazonia + western Amazonia) model, favored by SSDA, using our RADseq data in a coalescent framework. Pairwise Bayes Factors (BF) calculations selected both the 2-taxa $[\ln (B F)=10.4]$ and 3-taxa $[\ln (B F)=10.8]$ models as being significantly better than random species assignments using the Kass and Raftery (1995) scale; if $\ln (B F) \geq 5$ there is strong support for the model with the higher MLE. The pairwise comparison between 2-taxon (PTP) and 3-taxon (SSDA) models provided stronger support for the 3-taxon model [In $(B F)=9.5$ ] ( $\underline{\text { Table 3 }}$, Supplemental Fig. 4). To further examine the feasibility that $G$. humeralis from eastern and western Amazonia belong to distinct species, we tested whether our data supported reciprocal monophyly between the populations using topology tests by generating constraint trees for each dataset (trees not shown). Indeed, both SH and AU tests rejected the hypothesis that eastern and western Amazonian populations are reciprocally monophyletic, using the RADseq SNP data (SH p-value $<0.0001$, AU p-value $\sim 0$ ) and mtDNA data ( $\mathrm{SH}$ p-value $=0.0055$, AU p-value $=0.0006)$.

\section{Discussion}

Phylogenetic analyses recovered G. humeralis populations from Trinidad as sister to mainland populations, with a western Amazonian cladenested within populations from eastern Amazonia (Fig. 1, Fig. 2b). Furthermore, STRUCTURE analysis inferred three populations of alleles in Hardy-Weinberg equilibrium $(K=3)$, with no individuals belonging purely to the third "ghost" population ('purple'). This STRUCTURE pattern can be the result from two scenarios (Lawson et al., 2018): (1) admixture with an extinct/unsampled population or (2) genetic diversityin eastern Amazonia that did not establish in western populations, potentially through isolation-bydistance (IBD) mediated gene flow or a population bottleneck during stepwise westward range expansion. Distinguishing between scenarios (1) and (2) is difficult and they are not mutually exclusive. At present, testing for admixture, scenario 1, is not possible with our current sampling as individuals from the putative "ghost" population are also needed. It's possible that increased sampling across the Guiana Shield could identify $G$. humeralis populations that harbor an increased frequency of these "ghost alleles". Indeed, population differentiation in this region has been noted previously for other taxa (Noonan and Gaucher, 2005). However, we posit (2) is a more likely scenario, i.e. extensive genetic diversity specific to eastern Amazonian populations, for three reasons: (i) we found much greater genetic diversity in eastern Amazonia (Supplemental Table 3 ) and little evidence for shared mtDNA haplotypes between localities, as did Avila-Pires et al (2012), which would be expected under this scenario; (ii) we recovered a signal of IBD across the mainland, which could account for the eastern specificity of these alleles via dropout; and (iii) western Amazonian populations are monophyletic, which would be expected if there were a population bottleneck during westward colonization. However, apart from weighing these lines of evidence, the current state of knowledge and our current sampling provide no definitive way of differentiating them. Thus, future work may warrant further examination of these possibilities. 
Our phylogenetic and STRUCTURE results informed the possibility that Trinidadian divergence from the mainland is sufficient to warrant taxonomic reevaluation. Examining species limits using multiple methods and data types consistently identified the Trinidad populations as distinct species from the mainland populations, while a subset of analyses (SSDA \& BFD) further split populations from eastern and western Amazonia. We first address whether the Trinidad populations represent a distinct species from the mainland populations, and then discuss whether the South American populations consist of one or more species.

All species delimitation analyses recovered Trinidadian populations as being distinct from Amazonian $G$. humeralis (Table 2; Supplemental Figs. 3 and 4). Additionally, uncorrected genetic distances in mitochondrial ND2 (10\%) between Trinidad and eastern populations (Table 1) are comparable to mitochondrial genetic distances among other recognized sister species of geckos, which typically range from $4.1 \%$ to $35.5 \%$ (Botov et al., 2015, Grismer et al., 2014a, Grismer et al., 2014b, Grismer et al., 2017, Oliver et al., 2007, Pepper et al., 2006, Portik et al., 2013). Although species delimitation based solely on pre-determined sequence divergence values is difficult, if not impossible, to justify due to variations in effective population sizes and lineage-specific substitution rates (Barraclough et al., 2009, Moritz and Cicero, 2004, Pons et al., 2006), genetic distances among putative taxa can highlight taxa that warrant closer examination using other species delimitation methodologies (Gamble et al., 2012a, Hickerson et al., 2006), e.g. PTP, SSDA, and BFD. Thus, the bulk of the evidence supports recognition of the Trinidadian population as an independently evolving metapopulation lineage, or species ( $\underline{\text { de }}$ Queiroz, 2007), distinct from mainland G. humeralis. Because the type locality of $G$. humeralis is from Peru (Guichenot, 1855, Rivero-Blanco, 1979), mainland South American populations should retain that name. Geckos on Trinidad, however, were previously described as G. ferrugineus (Cope, 1864) and we resurrect that name from synonymy for the Trinidadian population and briefly discuss its unusual nominal history.

Gonatodes ferrugineus has a complex taxonomic history (see supplement for complete synonymy). Cope (1864) described G. ferrugineus from material collected on Trinidad that Theodore Gill deposited in the Smithsonian. Although the original description was ambiguous, and the type presumably lost (Rivero-Blanco, 1979), Cope (1868) later identified a G. ferrugineus specimen (presumably being unaware of G. humeralis) among a collection of lizards from Peru and thus later naturalists assumed that $G$. ferrugineus was morphologically similar-to, and perhaps a junior synonym of, G. humeralis (Guichenot, 1855). Gonatodes ferrugineuswas eventually synonymized with $G$. humeralis, although no justification was provided for the decision (Donoso-Barros, 1968). However, throughout the late 19th and most of the 20th centuries discrepancies in nomenclature were apparent. Some herpetologists appeared to be unaware of $G$. ferrugineus and listed $G$. humeralis as occurring on Trinidad, likely based on their own experiences with this species while working in South America (Parker, 1935, Roux, 1926). Others listed G. ferrugineus as occurring on Trinidad and G. humeralis on the mainland (Boulenger, 1885, Burt \& Burt, 1933). Wermuth (1965) added to the confusion by indicating that both $G$. ferrugineus and $G$. humeralis co-occur on Trinidad. However, following the explicit synonymy of Donoso-Barros (1968) and Rivero-Blanco's thorough scholarly review (1979), synonymy of $G$. ferrugineus with G. humeralis was unanimously accepted (Avila-Pires, 1995, Kluge, 1993, Kluge, 1995, Kluge, 2001).

Gonatodes ferrugineus is currently morphologically indistinguishable from $G$. humeralis although there appear to be some qualitative differences in proportionality of the face, body size, and coloration in adult males that may, upon further investigation, diagnose this species (Authors' pers. obs.; Rivero-Blanco, 1979). Coloration may be particularly useful as adult males from Trinidad are generally not as colorful as those from mainland South America (Supplemental Fig. 1). Trinidadian males lack red spots on the sides of the body and their heads tend to favor orange/yellow rather than red and white/blue, both of which are typical features of most South American populations (Authors' pers. obs.; Rivero-Blanco, 1979). Similarly-colored males to those from Trinidad have also been observed in northern Venezuela (Rivero-Blanco, 1979), leading to the possibility that $G$. ferrugineus occurs there as well (Supplemental Fig. 1). Indeed, several Trinidadian endemics exhibit distributions that extend into northern Venezuela, such as Gonatodes ceciliae, Gonatodes vittatus, Polychrus auduboni, and Flectonotus 
fitzgeraldi(Murphy, 1997, Murphy et al., 2017a). Further, previous studies that have examined morphological variation within G. humeralis have not included specimens from Trinidad (Avila-Pires, 1995, Avila-Pires et al., 2012, Vitt et al., 1997). Thus, future work should attempt to identify diagnostic phenotypic differences to complement the identified genotypic characters between these two species and determine the geographical boundaries of these species (Supplemental Fig. 1). It is worth pointing out a gap in our sampling from the northern Guiana Shield to Trinidad. Indeed, having not sampled Venezuelan populations may confound species delimitation metrics. However, we find this unlikely as we see no evidence of gene flow between Trinidad andthe mainland, even when $\mathrm{K}=2$ (Supplemental Fig. 2) and 9.4\% pairwise divergence at the mitochondrial locus ND2 is considerable, and likely reflects substantial reproductive isolation.

Although $G$. ferrugineus was revealed to be unambiguously distinct from mainland populations in all analyses, the status among South American populations was less straightforward. SSDA and BFD both provided support for a species delimitation model that splits mainland $G$. humeralis into two species, occupying eastern and western Amazonia (Table 2, Table 3, Supplemental Fig. 4). This hypothesis was bolstered by the fact that western Amazonia did not possess a large proportion of eastern-specific alleles (Fig. 1b) and that western Amazonia is monophyletic, although not reciprocally monophyletic with relation to eastern populations (Fig. 1a). These data are also congruent with previous work showing that the western Amazonian populations exhibit ecological differences compared to eastern populations. Namely, eastern G. humeralis occurs in primary forest, whereas western G. humeralis occur frequently in clearings, secondary forests, and human dwellings (Vitt et al., 1997). Additionally, a model that supports a parapatric mode of speciation across Amazonia would support the gradient hypothesis of Amazonian biogeography (Endler, 1977). However, there is emerging evidence that intraspecific, population-level processes can confound assumptions made by coalescent species delimitation methods, such as SSDA and BFD (Ahrens et al., 2016, Barley et al., 2018, Gratton et al., 2015, Sukumaran and Knowles, 2017). This includes processes such as IBD, which we identified in our mainland samples, that can result in oversplitting species even in well-represented, continuously sampled populations. When considered in conjunction with our relatively sparse sampling, particularly in central Amazonia (Fig. 1), it is most likely that SSDA and BFD mis-interpreted this structure as speciation, and thus oversplit the mainland clade. Additionally, for both the mtDNA and RADseq data, eastern and western populations are not reciprocally monophyletic. While reciprocal monophyly at any specific locus is not a prerequisite for species delimitation (Hudson and Coyne, 2002, Palumbi, 2001), rapidly coalescing loci like mtDNA frequently form monophyletic sister species, reflecting their reproductive isolation (Wiens and Penkrot, 2002, Zink and Barrowclough, 2008). Thus, the failure to recover reciprocal monophyly, coupled with high proportions of shared alleles between eastern and western lineages, supports a single-species hypothesis for mainland, i.e. G. humeralis sensu stricto.

Our estimates of the divergence time between mainland Amazonia and Trinidad are moderately disparate (mean = 1.89 mya (secondary calibration) and 2.7 mya (ND2 rate)). This is as expected, because gene divergence occurs prior to species divergence (Edwards and Beerli, 2000). Thus, we err on the side of the more-recent species divergence estimate of 1.89 mya (Fig. 2), which then suggests that cladogenesis between $G$. ferrugineus and $G$. humeralis took place in the early- to mid-Pleistocene, coinciding with the published divergences separating sister taxa in other organisms distributed on Trinidad and South America, including: fishes (Jowers et al., 2008), frogs (Camargo et al., 2009), skinks (Hedges and Conn, 2012), and birds (Hunt et al., 2001). Concordance across animal clades is suggestive of a large-scale isolating event between groups of organisms on Trinidad and South America during this time-period due to Pleistocene glacial cycles. However, these divergences are ancient considering recent connections between the Paria peninsula of Venezuela and Trinidad as recently as 10,000 years ago (Comeau, 1991). This transient connector may have also provided $G$. ferrugineus with the means of re-colonizing the mainland in a similar manner to $G$. ceciliaeand $G$. vittatus (Supplemental Fig. 1). This possibility presents an interesting testable hypothesis of testing codivergence of these lineages. Nonetheless, testing this hypothesis using a model-based biogeographic analysis (such as Ree et al., 2005) is currently not possible, as we are still lacking a fully sampled Gonatodes phylogeny (Gamble et al., 2008, Schargel et al., 2010, Russell et al., 2015). 
We are currently unable to devise definitive tests to differentiate between three competing phylogeographic scenarios: (1) Trinidad and mainland populations were isolated via vicariance during Pleistocene glacial cycles, (2) dispersal to Trinidad via river flotsam (from the Orinoco or other nearby river), or (3) the inverse scenario, dispersal to the mainland from Trinidad. Given the current data, we are unable to ascertain the approximate distribution of the most recent common ancestor to G. humeralis and G. ferrugineus. As discussed above, western Amazonian populations are nested within eastern populations of $G$. humeralis, excluding the possibility of an Andean origination (Fig. 1). G. humeralispossesses significantly greater genetic diversity in eastern Amazonia than G. ferrugineus, which suggests a founder effect bottleneck on Trinidad via (1) vicariance or (2) riverine dispersal and discourages (3) the inverse possibility of dispersal from Trinidad to South America (Supplemental Table 2). In many cases, high levels of genetic diversity correlate with a lineage's point-of-origin as genetic diversity accumulates over time in stable populations (Ingman et al., 2000, Kimura, 1983). In addition, most Gonatodes species occur in South America, including a member of G. humeralis sensu lato's sister group, $G$. conncinatus, suggesting a continental origin, with Caribbean species resulting from subsequent dispersals from the mainland (Supplemental Fig. 1), unlike Anolis lizards (Glor et al., 2001). However, several species closelyrelated to this clade, e.g. G. ocellatus, G. ceciliae, and G. antillensis (G. conncinatus' sister species), occur on islands north of South America, including Trinidad and Tobago (Supplemental Fig. 1). Thus, although the data are suggestive, these scenarios can, and should be, explicitly tested when sufficient data are available.

The identification of the recent radiation of $G$. humeralis across Amazonia provides a powerful framework for testing recent biogeographic theories using fine-scale sampling, given specific demographic and phylogeographic predictions (Avila-Pires et al., 2012, Bush and Oliveira, 2006, Haffer, 1997, Prates et al., 2016, Werneck et al., 2012). We found that $G$. humeralis does not diverge from a neutral model, suggesting a relatively constant population size over time. However, it is also known that small sample sizes (mainland $N=20$ ) can confound true deviations from neutrality, although failure to diverge from a neutral model is also a common theme in Amazonian taxa and is not unique to G. humeralis (Lessa et al., 2003). This is still somewhat surprising since the divergence between $G$. humeralis in eastern and western Amazonia has occurred so recently (Fig. 2). This shallow time-frame, however, provides the potential for Quaternary divergence hypotheses, namely the refuge (Haffer, 1969) and vanishing refuge (Vanzolini and Williams, 1981) hypotheses, to be tested by employing more fine-scale sampling than was available for this study. Thus, G. humeralis sensu stricto provides a model system for elucidating the recent history of Amazonia.

Within eastern Amazonia, our results are largely concordant with the findings of Avila-Pires et al. (2012), using mitochondrial data to infer high genetic diversity in eastern Amazonia (Supplemental Table 3 ). Along with the lack of genetic diversity in western Amazonia and on Trinidad, our data suggest the most recent common ancestor of $G$. humeralis sensu stricto occurred in eastern Amazonia, with subsequent westward expansion; as source populations typically have higher genetic diversity than their emigrated counterparts (Cann et al., 1987, Ingman et al., 2000). Previous investigations of geographic barriers that have affected G. humeralis have focused on riverine barriers (Avila-Pires et al., 2012). Rivers have played an important role in Amazonian biogeography by acting as barriers to gene flow in multiple taxa [Cracraft, 1985, Haffer, 1969, Oliveira et al., 2017, Wallace, 1852]. However, there is little evidence that they have had much impact on the present-day distribution of $G$. humeralis, as our time-calibrated phylogeny suggests that intraspecific divergence within $G$. humeralis took place $<2.4$ mya (Fig. 2), which is more recent than the establishment of the present-day Amazon river ( $\geq 3.6$ mya) or the paleo-Tocantins river ( $\approx 2.6$ mya) (Figueiredo et al., 2009 , Latrubesse et al., 2010). Future investigations, with more thorough geographic sampling, may be able to elucidate a role for riverine barriers in relation to migration and gene flow in G. humeralis. Furthermore, the adaptation(s) that have led to the unusually broad distribution of $G$. humeralis may be of greater macroevolutionary importance for further investigation. Here, we briefly discuss the current state of knowledge regarding $G$. humeralis' lineage-specific adaptations. 


\subsection{Gonatodes as a phylogeographic model system}

Gonatodes humeralis is distributed over a geographic range considerably larger than that of any of its congeners. Indeed, because most geckos exhibit small ranges, $G$. humeralis may possess one of the largest native ranges of any gecko species (Meiri et al., 2017, Roll et al., 2017). Gonatodes humeralis resembles its congeners in many respects, and there are several hypotheses to explain the large distribution of $G$. humeralis. The first involves increased thermal tolerance, which could allow $G$. humeralis to disperse across warm, open areas between forest fragments (Vanzolini and Williams, 1981). However, G. humeralis maintains the same body temperature as at least two congeners: G. concinnatus (Vitt and Zani, 1996); and G. hasemani (Vitt et al., 2000), and although it occupies slightly warmer microhabitats than $G$. hasemani, its thermal properties may be explained by differences in body size; as G. humeralis is the smallest member of its genus (Avila-Pires, 1995). To test this as a potential explanation for the relative success of $G$. humeralis, body and microhabitat temperatures for additional Gonatodes species will be needed (Hertz et al., 1993). Another hypothesis involves the presence of functionally adhesive digits in G. humeralis, and G. ferrugineus, a unique trait for these taxa (Higham et al., 2017, Russell et al., 2015).

The gain and loss of adhesive toepads in geckos has been hypothesized to represent a key innovation (Higham et al., 2017, Losos, 2011, Russell and Delaugerre, 2017). A key innovation is a behavioral or morphological adaptation that has the capacity to enhance competitive ability, relax adaptive trade-offs, or catalyze the exploitation of a novel resource, which, in turn enhances the number or longevity of a species (Hunter, 1998). Digital adhesion allows geckos to exploit vertical, low-friction surfaces and may have allowed $G$. humeralis to occupy habitats unavailable to its congeners, such as higher strata in the rainforest canopy or locomotion on a wide variety of substrates (Vitt et al., 1997, Russell et al., 2015). Although current genetic and fossil data are lacking to successfully correlate gain and loss of digital adhesion and diversification rates in geckos, it has been demonstrated that: (1) digital adhesion has been gained, and lost, multiple times throughout the evolutionary history of gecko lizards (Gekkota) (Gamble et al., 2012b), (2) under different environmental conditions, selection can favor the presence or absence of adhesive digits (Russell and Delaugerre, 2017), (3) the evolution of functional adhesion requires few morphological changes (Russell et al., 2015), and (4) small morphological changes can have marked impacts on function and the success of a lineage (Burggren, 1992, Higham et al., 2015, Higham et al., 2016, Hunter, 1998, Liem, 1973Russell, 1979, Thomason and Russell, 1986, Webb, 1982). Although, key innovations are generally discussed in the context of adaptive radiations(Farrell, 1998, Stroud and Losos, 2016), it is evident that we witness evolutionary processes as a snapshot in time and, given a strong environmental impetus, a well-adapted (successful) lineage with a broad range may also be a lineage that is primed for subsequent diversification (Endler, 1977, Haffer, 1969). Thus, digital adhesion, which is absent from all other Gonatodes species, provides a putative mechanism for $G$. humeralis sensu lato, relative to other members of the genus, to have capitalized on available ecological opportunity across Amazonia and on Trinidad (see [Wellborn and Langerhans, 2014] for a scholarly review of ecological opportunity).

\section{Conclusion}

We propose that G. humeralis sensu lato is composed of two species. (1) G. humeralis sensu stricto occupies mainland South America and (2) its sister species, G. ferrugineus, resides allopatrically on the island of Trinidad. However, we reject the hypothesis that $G$. humeralis is a species-complex made up of multiple species across Amazonia. More specifically, genetic analyses support the hypothesis that $G$. humeralis sensu stricto is a single species throughout its contiguous range across northern South America with substantial population structure (local diversity and IBD). This is extremely atypical for a small, non-volant Neotropical taxon, and this pattern contrasts with that of most Amazonian taxa, as well as other species of Gonatodes, which occupy small, disjunctive distributions, and this discrepancy in geographic range invites further investigation. Indeed, unlike many clades consisting of widespread Neotropical taxa, Gonatodes harbors both widespread and geographically restricted taxa, providing a powerful system for identifying traits that influence species distributions. Thus, future work should attempt to elucidate the evolutionary adaptations that have influenced the biogeography of Gonatodes. 


\section{Author contributions}

B.J.P. assisted in study design, performed lab work, analyzed data, and wrote the manuscript. G.R.C. conducted fieldwork. T.E.H. assisted in study design. A.P.R. assisted in study design and manuscript preparation. D.P.S. and L.J.V. conducted fieldwork. T.G. conducted fieldwork, assisted in study design, performed lab work, and manuscript preparation. In addition, all authors read and approved the final manuscript.

\section{Acknowledgements}

Authors would like to thank S. Estrada-Villegas, S.V. Nielsen, and A.H. Griffing for helpful comments and insightful discussion on early drafts of the manuscript; anonymous reviewers for constructive and helpful comments on the manuscript; S. Meiri for providing data for our geographic area estimations; A. Schultz and A. M. Simons for lab help on an earlier iteration of this project; and Ambrose Monell Cryo Collection (AMCC) at the American Museum of Natural History, R. Brumfield and LSU Museum of Natural Science Collection of Genetic Resources, M. Forstner, R. M. Murphy (ROM), J. Simmons (KU), and G. Watkins-Colwell (YPM) provided tissues from material in their care. B. J. Pinto was supported in-part by NSF DEB1657662 (to T. Gamble); G. R. Colli thanks Coordenação de Apoio à Formação de Pessoal de Nível Superior (CAPES), Conselho Nacional de Desenvolvimento Científico e Tecnológico (CNPq), Fundação de Apoio à Pesquisa do Distrito Federal (FAPDF), and the Partnerships for Enhanced Engagement in Research (PEER) program for financial support. This work was also funded by National Science Foundation (NSF) IOS grant (1147043) and start-up funds from UC Riverside to T. E. Higham, The Natural Sciences and Engineering Research Council of Canada Discovery Grant (9745-2008) to A. P. Russell, NSF DDIG (DEB-1110605) to D. P. Scantlebury, the University of Oklahoma Research Council via a George Lynn Cross Research Professorship to L. J. Vitt, NSF IOS grant (1146820) to D. Zarkower, and start-up funds (Marquette University) and Dayton/Wilkie Fund (Bell Museum of Natural History) to T. Gamble.

\section{Data accessibility}

GenBank and Short Read Archive (SRA) accession numbers provided in Supplemental Table 1.

\section{Appendix A. Supplementary material}

The following are the Supplementary data to this article:

\section{Supplementary data 1.}

Supplementary Figure 1. Gonatodes humeralis occurs sympatrically across its range with 13 congeners: $G$. alexandermendensi, G. annularis, G. ceciliae, G. conncinatus, G. eladoi, G. hasemani, G. nascimento, G. riveroi, G. rozei, G. seigliei, G. tapajonicus, G. timidus, and G. vittatus. All range estimates are based upon museum records from Universidad Nacional de Colombia and from the literature: Avila-Pires, 1995; Carvajal-Campos \& Torres-Carvajal, 2012; Meilink et al. 2013; Ribeiro-Junior, 2015; Rivas \& Schargel, 2008; Rivero-Blanco, 1979; Schargel et al. 2017; Uetz, 2017; Vanzolini, 1955; Vitt \& Zani, 1996; Vitt et al. 1997 \& 2000. Bottom right: Proposed species range adjustments concluded from this study, i.e. dividing G. humeralis and G. ferrugineus. "?" denotes the findings of Rivero-Blanco (1979) where male specimens from northern Venezuela more closely resemble specimens from Trinidad leading to the possibility that this is $\mathrm{G}$. ferrugineus. Bottom: Representative photographs of each species G. humeralis courtesy of L.J.V. and G. ferrugineus courtesy of D.P.S. 


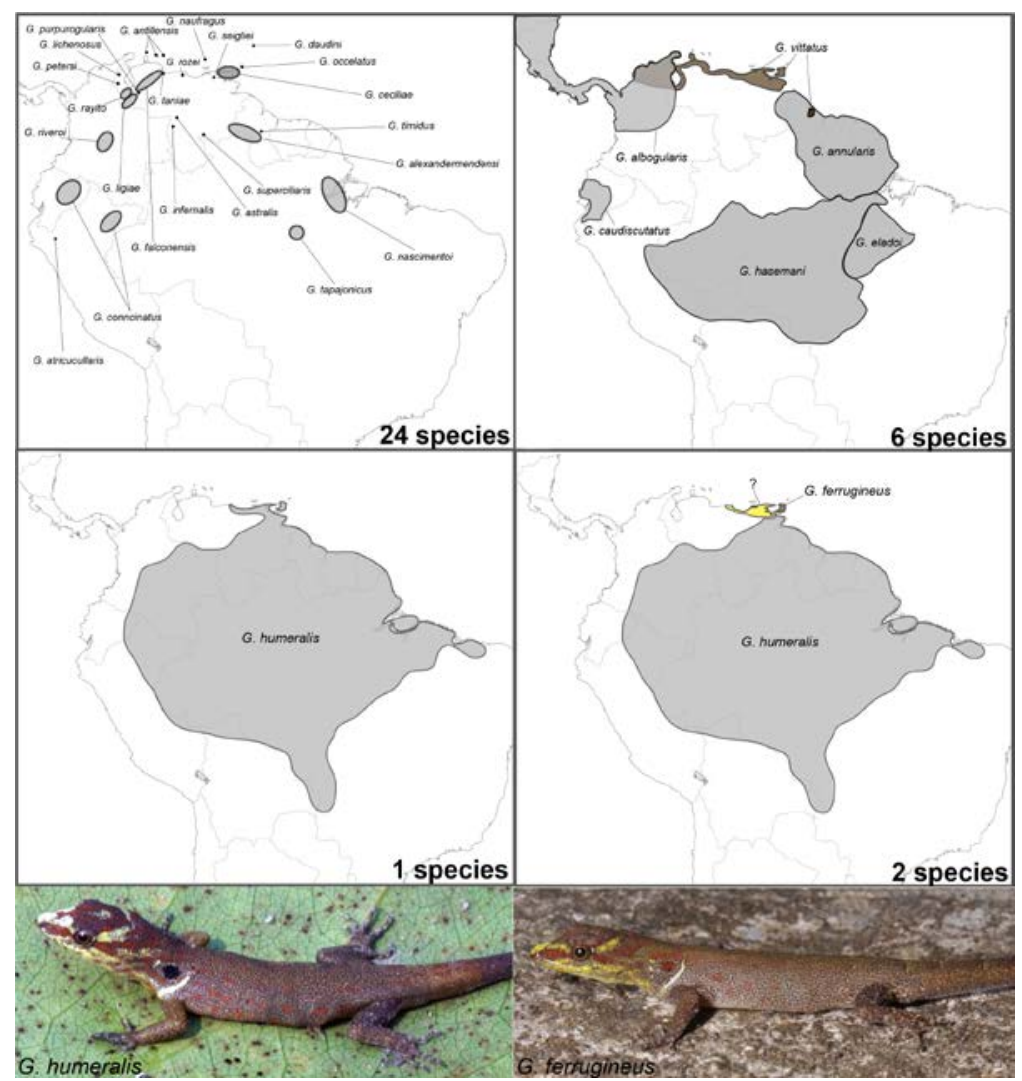

\section{Supplementary data 2.}

Supplementary Figure 2. Distruct plot output of STRUCTURE software investigating proportions of shared alleles among 16,381 unlinked SNPs with $K=1-6$. Line graph depicting deltaK $=\left[\operatorname{mean}\left(\left|\mathrm{L}^{\prime \prime}(\mathrm{K})\right|\right) / \mathrm{sd}(\mathrm{L}(\mathrm{K}))\right]$ over iteration of each $\mathrm{K}$.
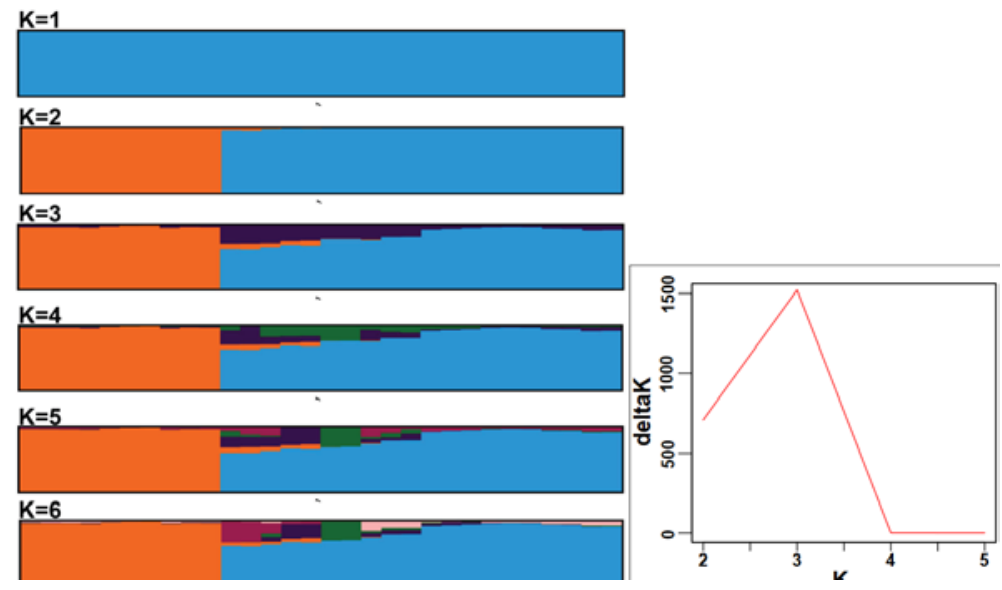

\section{Supplementary data 3.}

Supplementary Figure 3. Poisson Tree Processes (PTP) annotated mitochondrial tree output indicating distinct species as red clades with green root. The same tree is shown in an expanded cladogram format reporting nodal support of the mtDNA tree (posterior probabilities $\geq 0.95$ ). 


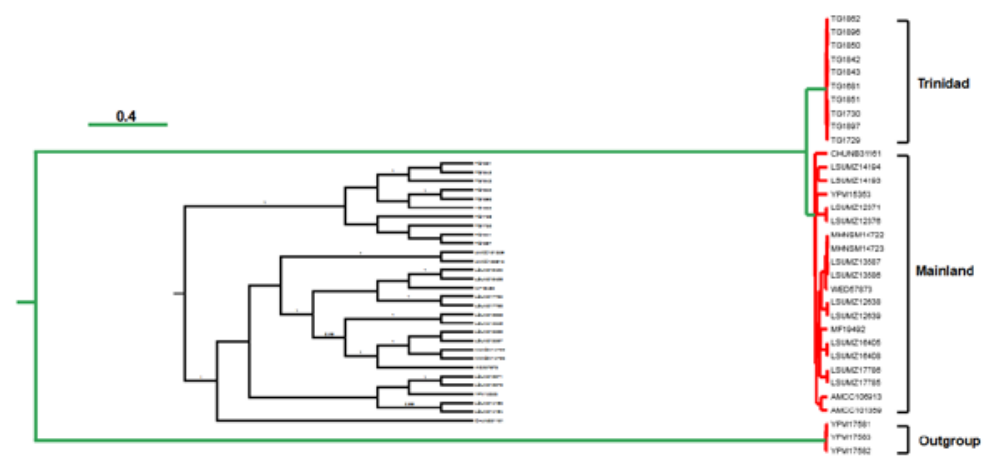

\section{Supplementary data 4.}

Supplementary Figure 4. Top left: map relating locality data to location on representative trees. Bottom left: (PTP) Species delimitation model predicted by PTP analysis using mitochondrial gene tree. Top right: (SSDA STACEY) Species delimitation model predicted by SSDA in a Bayesian coalescent framework, support values for each node correspond to posterior probabilities that indicate each node is a distinct species under six different demographic scenarios (see methods). Bottom right: (BFD) Species delimitation model supported by BFD, reported number $[\ln (B F)=9.5]$ reflecting a model comparison between the two-species $(P T P)$ and three-species (SSDA) models by comparing Bayes factors (see methods). Dash marks along branch lengths represent that the lineage beyond is supported as a species-level clade in that respective analysis.

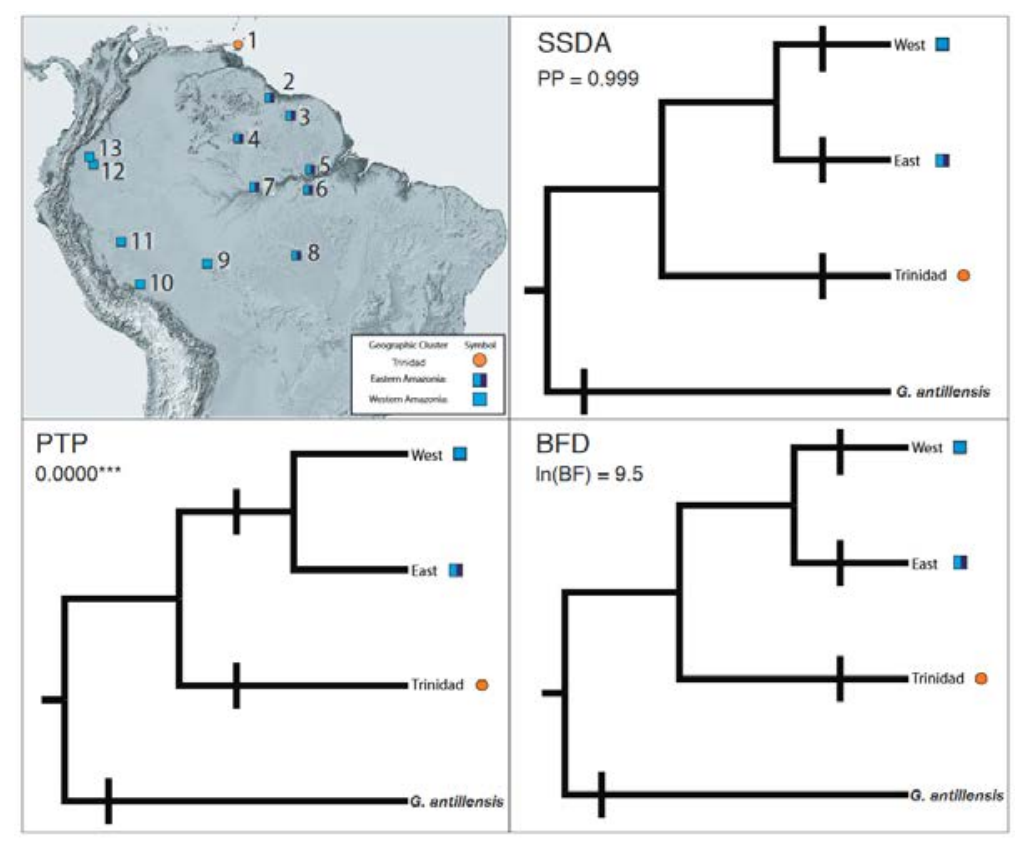

\section{Supplementary data 5.}

Supplementary Figure 5. Bayesian time-calibrated phylogenetic reconstruction using a secondary timecalibrated root acquired from Gamble et al. (2015), set at $\approx 72.5$ million years with a normal distribution $(\sigma=4)$. Posterior probabilities reported at each node with colored circles where large red circles are equal to posterior probability equal to $\geq 0.99$, while smaller blue circles are equal to less than 0.95 (unsupported). Mean node ages are reported with node bars indicating $95 \%$ confidence interval of each mean age. 


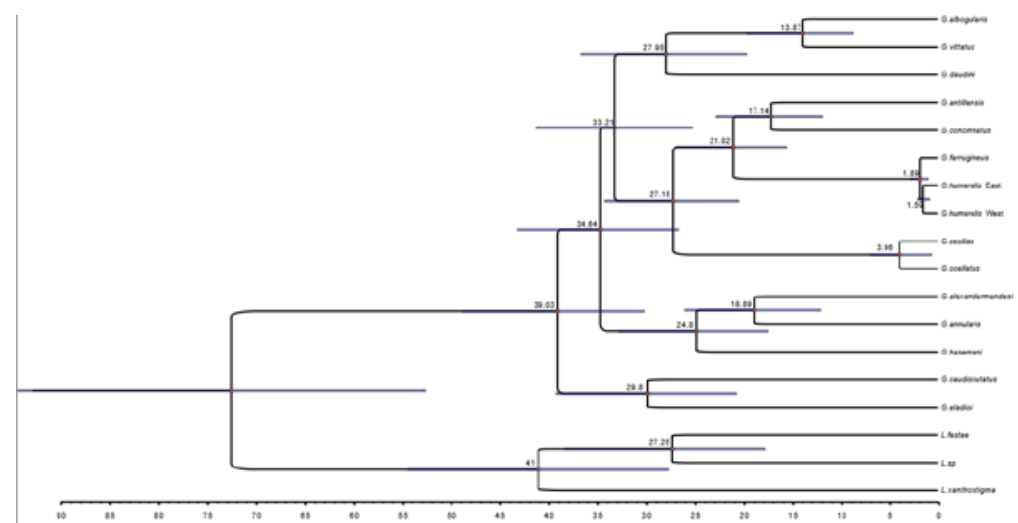

Supplementary data 6.

Supplementary Figure 6. Bayesian phylogenetic reconstruction using STACEY. (A) Maximum sum of clade credibility tree summarized from 27,003 post-burnin trees, numbers are posterior support for the associated node. (B) DensiTree representation of 27,003 post-burnin trees.

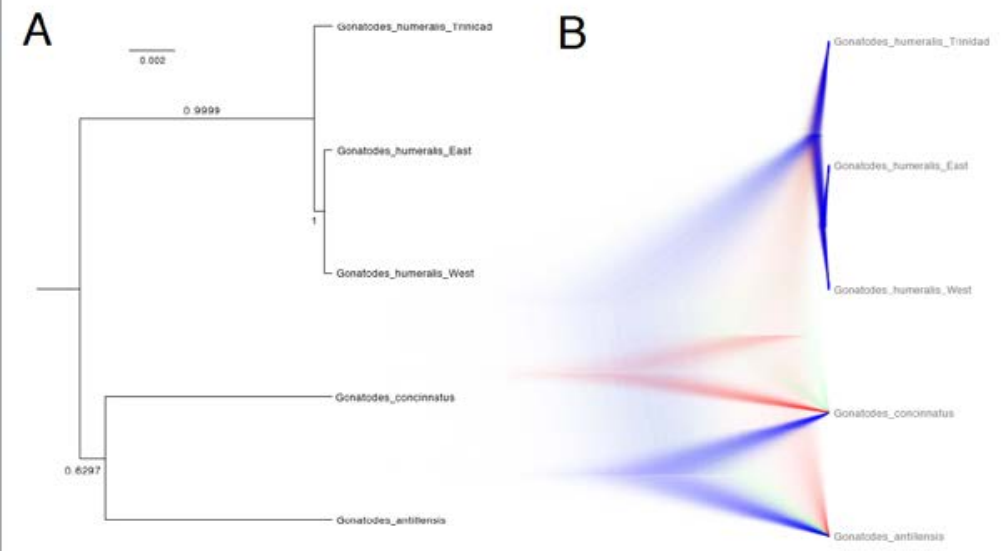

Supplementary data 7.

Supplementary Table 1. Locality and GenBank accessibility information of data generated in this study.

\begin{tabular}{|c|c|c|c|c|c|c|c|c|c|c|}
\hline Species & $\begin{array}{l}\text { Specim } \\
\text { en ID }\end{array}$ & Locality & $\begin{array}{l}\text { Locali } \\
\text { ty ID }\end{array}$ & $16 S$ & ND2 & $\begin{array}{l}\text { RAG } \\
1\end{array}$ & $\begin{array}{l}\text { CMO } \\
S\end{array}$ & $\begin{array}{l}\text { PTPN } \\
12\end{array}$ & $\begin{array}{l}\text { MAP } \\
1 b\end{array}$ & Radseq \\
\hline $\begin{array}{l}G . \\
\text { ferrugi } \\
\text { neus }\end{array}$ & TG1681 & Biche, Trinidad & 1 & $\begin{array}{l}K X 76 \\
2113\end{array}$ & $\begin{array}{l}K X 76 \\
2236\end{array}$ & $\begin{array}{l}K X 76 \\
2207\end{array}$ & $\begin{array}{l}K X 76 \\
2257\end{array}$ & $\begin{array}{l}\text { KX76 } \\
2141\end{array}$ & $\begin{array}{l}K X 76 \\
2166\end{array}$ & $\begin{array}{l}\text { SAMN06 } \\
827899\end{array}$ \\
\hline $\begin{array}{l}\text { G. } \\
\text { ferrugi } \\
\text { neus }\end{array}$ & TG1729 & $\begin{array}{l}\text { Flanagin Town, } \\
\text { Trinidad }\end{array}$ & 1 & $\begin{array}{l}K \times 76 \\
2114\end{array}$ & $\begin{array}{l}K X 76 \\
2237\end{array}$ & $\begin{array}{l}K X 76 \\
2208\end{array}$ & $\begin{array}{l}K X 76 \\
2250\end{array}$ & $\begin{array}{l}K X 76 \\
2142\end{array}$ & $\begin{array}{l}\text { KX76 } \\
2167\end{array}$ & $\begin{array}{l}\text { SAMN06 } \\
827900\end{array}$ \\
\hline $\begin{array}{l}\text { G. } \\
\text { ferrugi } \\
\text { neus }\end{array}$ & TG1730 & $\begin{array}{l}\text { Flanagin Town, } \\
\text { Trinidad }\end{array}$ & 1 & $\begin{array}{l}K \times 76 \\
2115\end{array}$ & $\begin{array}{l}K X 76 \\
2238\end{array}$ & $\begin{array}{l}K X 76 \\
2209\end{array}$ & $\begin{array}{l}K X 76 \\
2255\end{array}$ & $\begin{array}{l}K X 76 \\
2143\end{array}$ & $\begin{array}{l}K X 76 \\
2168\end{array}$ & $\begin{array}{l}\text { SAMN06 } \\
827901\end{array}$ \\
\hline $\begin{array}{l}G . \\
\text { ferrugi } \\
\text { neus }\end{array}$ & TG1842 & Biche, Trinidad & 1 & $\begin{array}{l}K X 76 \\
2116\end{array}$ & $\begin{array}{l}K X 76 \\
2239\end{array}$ & $\begin{array}{l}K X 76 \\
2210\end{array}$ & $\begin{array}{l}K X 75 \\
7678\end{array}$ & $\begin{array}{l}K X 76 \\
2144\end{array}$ & $\begin{array}{l}K X 76 \\
2169\end{array}$ & $\begin{array}{l}\text { SAMN06 } \\
827902\end{array}$ \\
\hline $\begin{array}{l}G . \\
\text { ferrugi } \\
\text { neus }\end{array}$ & TG1843 & Biche, Trinidad & 1 & $\begin{array}{l}\text { KX76 } \\
2117\end{array}$ & $\begin{array}{l}K X 76 \\
2240\end{array}$ & $\begin{array}{l}K X 77 \\
4276\end{array}$ & N/A. & $\begin{array}{l}K X 77 \\
4278\end{array}$ & $\begin{array}{l}K X 76 \\
2170\end{array}$ & $\begin{array}{l}\text { SAMN06 } \\
827903\end{array}$ \\
\hline
\end{tabular}




\begin{tabular}{|c|c|c|c|c|c|c|c|c|c|c|}
\hline $\begin{array}{l}\text { G. } \\
\text { ferrugi } \\
\text { neus }\end{array}$ & TG1850 & $\begin{array}{l}\text { Flanagin Town, } \\
\text { Trinidad }\end{array}$ & 1 & $\begin{array}{l}\text { KX76 } \\
2118\end{array}$ & $\begin{array}{l}\mathrm{KX76} \\
2241\end{array}$ & $\begin{array}{l}K X 76 \\
2211\end{array}$ & $\begin{array}{l}K X 76 \\
2254\end{array}$ & $\begin{array}{l}K X 76 \\
2145\end{array}$ & $\begin{array}{l}K X 76 \\
2171\end{array}$ & $\begin{array}{l}\text { SAMN06 } \\
827904\end{array}$ \\
\hline $\begin{array}{l}\text { G. } \\
\text { ferrugi } \\
\text { neus }\end{array}$ & TG1851 & $\begin{array}{l}\text { Flanagin Town, } \\
\text { Trinidad }\end{array}$ & 1 & $\begin{array}{l}\mathrm{KX76} \\
2119\end{array}$ & $\begin{array}{l}K X 76 \\
2242\end{array}$ & $\begin{array}{l}\mathrm{KX76} \\
2212\end{array}$ & $\begin{array}{l}K X 76 \\
2253\end{array}$ & $\begin{array}{l}K X 76 \\
2146\end{array}$ & $\begin{array}{l}K X 76 \\
2172\end{array}$ & $\begin{array}{l}\text { SAMN06 } \\
827905\end{array}$ \\
\hline $\begin{array}{l}\text { G. } \\
\text { ferrugi } \\
\text { neus }\end{array}$ & TG1862 & $\begin{array}{l}\text { Flanagin Town, } \\
\text { Trinidad }\end{array}$ & 1 & $\begin{array}{l}K X 76 \\
2120\end{array}$ & $\begin{array}{l}K X 76 \\
2243\end{array}$ & $\begin{array}{l}K X 76 \\
2213\end{array}$ & $\begin{array}{l}K X 76 \\
2252\end{array}$ & $\begin{array}{l}\text { KX76 } \\
2147\end{array}$ & $\begin{array}{l}\text { KX76 } \\
2173\end{array}$ & $\begin{array}{l}\text { SAMN06 } \\
827906\end{array}$ \\
\hline $\begin{array}{l}\text { G. } \\
\text { ferrugi } \\
\text { neus }\end{array}$ & TG1896 & $\begin{array}{l}\text { Flanagin Town, } \\
\text { Trinidad }\end{array}$ & 1 & $\begin{array}{l}K X 76 \\
2121\end{array}$ & $\begin{array}{l}K X 76 \\
2244\end{array}$ & $\begin{array}{l}K X 76 \\
2214\end{array}$ & $\begin{array}{l}K X 76 \\
2256\end{array}$ & $\begin{array}{l}K X 76 \\
2148\end{array}$ & $\begin{array}{l}K X 76 \\
2174\end{array}$ & $\begin{array}{l}\text { SAMN06 } \\
827907\end{array}$ \\
\hline $\begin{array}{l}\text { G. } \\
\text { ferrugi } \\
\text { neus }\end{array}$ & TG1897 & $\begin{array}{l}\text { Flanagin Town, } \\
\text { Trinidad }\end{array}$ & 1 & $\begin{array}{l}\mathrm{KX76} \\
2122\end{array}$ & $\begin{array}{l}K X 76 \\
2245\end{array}$ & $\begin{array}{l}K X 77 \\
4277\end{array}$ & $\begin{array}{l}K X 76 \\
2251\end{array}$ & $\begin{array}{l}K X 77 \\
4279\end{array}$ & N/A. & $\begin{array}{l}\text { SAMN06 } \\
827908\end{array}$ \\
\hline $\begin{array}{l}\text { G. } \\
\text { humera } \\
\text { lis }\end{array}$ & $\begin{array}{l}\text { AMCC1 } \\
01359\end{array}$ & $\begin{array}{l}\text { Kwakwani, Berbice } \\
\text { River, Guyana }\end{array}$ & 2 & $\begin{array}{l}\text { EU47 } \\
7057\end{array}$ & $\begin{array}{l}\text { KX76 } \\
2218\end{array}$ & $\begin{array}{l}K X 76 \\
2193\end{array}$ & $\begin{array}{l}K X 76 \\
2179\end{array}$ & $\begin{array}{l}\text { KX76 } \\
2126\end{array}$ & $\begin{array}{l}K X 76 \\
2152\end{array}$ & $\begin{array}{l}\text { SAMN06 } \\
827879\end{array}$ \\
\hline $\begin{array}{l}\text { G. } \\
\text { humera } \\
\text { lis }\end{array}$ & $\begin{array}{l}\text { AMCC1 } \\
06913\end{array}$ & $\begin{array}{l}\text { Dubulay Ranch, } \\
\text { Berbice River, } \\
\text { Guyana }\end{array}$ & 2 & $\begin{array}{l}\text { EU47 } \\
7055\end{array}$ & $\begin{array}{l}\mathrm{KX76} \\
2219\end{array}$ & N/A. & N/A. & N/A. & N/A. & $\begin{array}{l}\text { SAMN06 } \\
827880\end{array}$ \\
\hline $\begin{array}{l}\text { G. } \\
\text { humera } \\
\text { lis }\end{array}$ & $\begin{array}{l}\text { YPM15 } \\
353\end{array}$ & $\begin{array}{l}\text { Kappel, Sipali District, } \\
\text { Suriname }\end{array}$ & 3 & $\begin{array}{l}\text { EF56 } \\
4012\end{array}$ & $\begin{array}{l}K X 76 \\
2247\end{array}$ & N/A. & N/A. & N/A. & N/A. & $\begin{array}{l}\text { SAMN06 } \\
827898\end{array}$ \\
\hline $\begin{array}{l}\text { G. } \\
\text { humera } \\
\text { lis }\end{array}$ & $\begin{array}{l}\text { LSUMZ } \\
12371\end{array}$ & $\begin{array}{l}\text { Faz. Nova Esperanca, } \\
\text { Roraima, Brazil }\end{array}$ & 4 & $\begin{array}{l}\text { EU47 } \\
7058\end{array}$ & $\begin{array}{l}K X 76 \\
2222\end{array}$ & $\begin{array}{l}K X 76 \\
2194\end{array}$ & $\begin{array}{l}K X 76 \\
2180\end{array}$ & $\begin{array}{l}K X 76 \\
2127\end{array}$ & $\begin{array}{l}K X 76 \\
2153\end{array}$ & $\begin{array}{l}\text { SAMN06 } \\
827882\end{array}$ \\
\hline $\begin{array}{l}\text { G. } \\
\text { humera } \\
\text { lis }\end{array}$ & $\begin{array}{l}\text { LSUMZ } \\
12376\end{array}$ & $\begin{array}{l}\text { Faz. Nova Esperanca, } \\
\text { Roraima, Brazil }\end{array}$ & 4 & $\begin{array}{l}\text { EU47 } \\
7056\end{array}$ & $\begin{array}{l}K X 76 \\
2223\end{array}$ & N/A. & N/A. & N/A. & N/A. & $\begin{array}{l}\text { SAMN06 } \\
827883\end{array}$ \\
\hline $\begin{array}{l}\text { G. } \\
\text { humera } \\
\text { lis }\end{array}$ & $\begin{array}{l}\text { CHUNB } \\
31161\end{array}$ & $\begin{array}{l}\text { Monte Alegre, Pará, } \\
\text { Brazil }\end{array}$ & 5 & $\begin{array}{l}\text { EF56 } \\
4040\end{array}$ & $\begin{array}{l}K X 76 \\
2220\end{array}$ & N/A. & $\begin{array}{l}\text { EF56 } \\
4092\end{array}$ & N/A. & N/A. & $\begin{array}{l}\text { SAMN06 } \\
827881\end{array}$ \\
\hline $\begin{array}{l}\text { G. } \\
\text { humera } \\
\text { lis }\end{array}$ & $\begin{array}{l}\text { LSUMZ } \\
14193\end{array}$ & $\begin{array}{l}\text { Santarem, Pará, } \\
\text { Brazil }\end{array}$ & 6 & $\begin{array}{l}\text { EF56 } \\
4031\end{array}$ & $\begin{array}{l}K X 76 \\
2224\end{array}$ & $\begin{array}{l}K X 76 \\
2196\end{array}$ & $\begin{array}{l}\text { EF56 } \\
4085\end{array}$ & $\begin{array}{l}\text { KX76 } \\
2129\end{array}$ & $\begin{array}{l}\text { KX76 } \\
2155\end{array}$ & $\begin{array}{l}\text { SAMN06 } \\
827888\end{array}$ \\
\hline $\begin{array}{l}\text { G. } \\
\text { humera } \\
\text { lis }\end{array}$ & $\begin{array}{l}\text { LSUMZ } \\
14194\end{array}$ & $\begin{array}{l}\text { Santarem, Pará, } \\
\text { Brazil }\end{array}$ & 6 & $\begin{array}{l}\text { EF56 } \\
4029\end{array}$ & $\begin{array}{l}K X 76 \\
2225\end{array}$ & $\begin{array}{l}K X 76 \\
2195\end{array}$ & $\begin{array}{l}K X 76 \\
2181\end{array}$ & $\begin{array}{l}K X 76 \\
2128\end{array}$ & $\begin{array}{l}K X 76 \\
2154\end{array}$ & $\begin{array}{l}\text { SAMN06 } \\
827889\end{array}$ \\
\hline $\begin{array}{l}\text { G. } \\
\text { humera } \\
\text { lis }\end{array}$ & $\begin{array}{l}\text { LSUMZ } \\
16405\end{array}$ & $\begin{array}{l}\text { Castanho, Amazonas, } \\
\text { Brazil }\end{array}$ & 7 & $\begin{array}{l}\text { EU47 } \\
7063\end{array}$ & $\begin{array}{l}K X 76 \\
2230\end{array}$ & $\begin{array}{l}K X 76 \\
2201\end{array}$ & $\begin{array}{l}K X 76 \\
2184\end{array}$ & $\begin{array}{l}\text { KX76 } \\
2134\end{array}$ & $\begin{array}{l}K X 76 \\
2160\end{array}$ & $\begin{array}{l}\text { SAMN06 } \\
827890\end{array}$ \\
\hline $\begin{array}{l}\text { G. } \\
\text { humera } \\
\text { lis }\end{array}$ & $\begin{array}{l}\text { LSUMZ } \\
16408\end{array}$ & $\begin{array}{l}\text { Castanho, Amazonas, } \\
\text { Brazil }\end{array}$ & 7 & $\begin{array}{l}\text { EU47 } \\
7062\end{array}$ & $\begin{array}{l}\text { KX76 } \\
2231\end{array}$ & $\begin{array}{l}K X 76 \\
2202\end{array}$ & $\begin{array}{l}K X 76 \\
2185\end{array}$ & $\begin{array}{l}K X 76 \\
2135\end{array}$ & $\begin{array}{l}K X 76 \\
2161\end{array}$ & $\begin{array}{l}\text { SAMN06 } \\
827891\end{array}$ \\
\hline $\begin{array}{l}\text { G. } \\
\text { humera } \\
\text { lis }\end{array}$ & $\begin{array}{l}\text { CHUNB } \\
47049\end{array}$ & $\begin{array}{l}\text { Alta Floresta, Mato } \\
\text { Grosso, Brazil }\end{array}$ & 8 & $\begin{array}{l}\text { EU47 } \\
7054\end{array}$ & $\begin{array}{l}\mathrm{KX76} \\
2221\end{array}$ & N/A. & N/A. & N/A. & N/A. & N/A. \\
\hline
\end{tabular}




\begin{tabular}{|c|c|c|c|c|c|c|c|c|c|c|}
\hline $\begin{array}{l}\text { G. } \\
\text { humera } \\
\text { lis }\end{array}$ & $\begin{array}{l}\text { LSUMZ } \\
17785\end{array}$ & $\begin{array}{l}\text { Guajará-Mirim, } \\
\text { Rondônia, Brazil }\end{array}$ & 9 & $\begin{array}{l}\text { EU47 } \\
7065\end{array}$ & $\begin{array}{l}K X 76 \\
2232\end{array}$ & $\begin{array}{l}K X 76 \\
2203\end{array}$ & $\begin{array}{l}K X 76 \\
2186\end{array}$ & $\begin{array}{l}K X 76 \\
2136\end{array}$ & $\begin{array}{l}K X 76 \\
2162\end{array}$ & $\begin{array}{l}\text { SAMN06 } \\
827892\end{array}$ \\
\hline $\begin{array}{l}\text { G. } \\
\text { humera } \\
\text { lis }\end{array}$ & $\begin{array}{l}\text { LSUMZ } \\
17786\end{array}$ & $\begin{array}{l}\text { Guajará-Mirim, } \\
\text { Rondônia, Brazil }\end{array}$ & 9 & $\begin{array}{l}\text { EU47 } \\
7064\end{array}$ & $\begin{array}{l}K X 76 \\
2233\end{array}$ & $\begin{array}{l}\text { KX76 } \\
2204\end{array}$ & $\begin{array}{l}\text { KX76 } \\
2187\end{array}$ & $\begin{array}{l}K X 76 \\
2137\end{array}$ & $\begin{array}{l}\text { KX76 } \\
2163\end{array}$ & $\begin{array}{l}\text { SAMN06 } \\
827893\end{array}$ \\
\hline $\begin{array}{l}\text { G. } \\
\text { humera } \\
\text { lis }\end{array}$ & $\begin{array}{l}\text { MHNS } \\
\text { M1472 } \\
2\end{array}$ & $\begin{array}{l}\text { Cuzco Amazònico, } \\
\text { Madre de Dios, Peru }\end{array}$ & 10 & $\begin{array}{l}\text { EU47 } \\
7067\end{array}$ & $\begin{array}{l}\text { KX76 } \\
2234\end{array}$ & $\begin{array}{l}\text { KX76 } \\
2205\end{array}$ & $\begin{array}{l}\text { KX76 } \\
2188\end{array}$ & $\begin{array}{l}K X 76 \\
2138\end{array}$ & $\begin{array}{l}K X 76 \\
2164\end{array}$ & $\begin{array}{l}\text { SAMN06 } \\
827895\end{array}$ \\
\hline $\begin{array}{l}\text { G. } \\
\text { humera } \\
\text { lis }\end{array}$ & $\begin{array}{l}\text { MHNS } \\
\text { M1472 } \\
3\end{array}$ & $\begin{array}{l}\text { Cuzco Amazònico, } \\
\text { Madre de Dios, Peru }\end{array}$ & 10 & $\begin{array}{l}\text { EU47 } \\
7068\end{array}$ & $\begin{array}{l}K X 76 \\
2235\end{array}$ & $\begin{array}{l}K X 76 \\
2206\end{array}$ & $\begin{array}{l}K X 76 \\
2189\end{array}$ & $\begin{array}{l}K X 76 \\
2139\end{array}$ & $\begin{array}{l}K X 76 \\
2165\end{array}$ & $\begin{array}{l}\text { SAMN06 } \\
827896\end{array}$ \\
\hline $\begin{array}{l}\text { G. } \\
\text { humera } \\
\text { lis }\end{array}$ & $\begin{array}{l}\text { WED57 } \\
873\end{array}$ & $\begin{array}{l}\text { Cuzco Amazònico, } \\
\text { Madre de Dios, Peru }\end{array}$ & 10 & $\begin{array}{l}\text { EF56 } \\
4028\end{array}$ & $\begin{array}{l}K X 76 \\
2246\end{array}$ & $\begin{array}{l}K X 76 \\
2215\end{array}$ & $\begin{array}{l}\text { EF56 } \\
4082\end{array}$ & $\begin{array}{l}K X 76 \\
2140\end{array}$ & $\begin{array}{l}\mathrm{KX76} \\
2175\end{array}$ & $\begin{array}{l}\text { SAMN06 } \\
827897\end{array}$ \\
\hline $\begin{array}{l}\text { G. } \\
\text { humera } \\
\text { lis }\end{array}$ & $\begin{array}{l}\text { LSUMZ } \\
13586\end{array}$ & $\begin{array}{l}\text { Porto Walter, Acre, } \\
\text { Brazil }\end{array}$ & 11 & $\begin{array}{l}\text { EU47 } \\
7069\end{array}$ & $\begin{array}{l}\text { KX76 } \\
2228\end{array}$ & $\begin{array}{l}\text { KX76 } \\
2199\end{array}$ & $\begin{array}{l}K \times 76 \\
2183\end{array}$ & $\begin{array}{l}K X 76 \\
2132\end{array}$ & $\begin{array}{l}K X 76 \\
2158\end{array}$ & $\begin{array}{l}\text { SAMN06 } \\
827886\end{array}$ \\
\hline $\begin{array}{l}\text { G. } \\
\text { humera } \\
\text { lis }\end{array}$ & $\begin{array}{l}\text { LSUMZ } \\
13587\end{array}$ & $\begin{array}{l}\text { Porto Walter, Acre, } \\
\text { Brazil }\end{array}$ & 11 & $\begin{array}{l}\text { EU47 } \\
7066\end{array}$ & $\begin{array}{l}\text { KX76 } \\
2229\end{array}$ & $\begin{array}{l}K \times 76 \\
2200\end{array}$ & N/A. & $\begin{array}{l}K X 76 \\
2133\end{array}$ & $\begin{array}{l}K X 76 \\
2159\end{array}$ & $\begin{array}{l}\text { SAMN06 } \\
827887\end{array}$ \\
\hline $\begin{array}{l}\text { G. } \\
\text { humera } \\
\text { lis }\end{array}$ & $\begin{array}{l}\text { MF194 } \\
92\end{array}$ & $\begin{array}{l}\text { Orellana, Napo, } \\
\text { Ecuador }\end{array}$ & 12 & $\begin{array}{l}\text { EF56 } \\
4013\end{array}$ & $\begin{array}{l}J X 04 \\
1361\end{array}$ & $\begin{array}{l}\text { EF53 } \\
4796\end{array}$ & $\begin{array}{l}\text { EF53 } \\
4922\end{array}$ & $\begin{array}{l}J F 41 \\
6860\end{array}$ & N/A. & $\begin{array}{l}\text { SAMN06 } \\
827894\end{array}$ \\
\hline $\begin{array}{l}\text { G. } \\
\text { humera } \\
\text { lis }\end{array}$ & $\begin{array}{l}\text { LSUMZ } \\
12638\end{array}$ & $\begin{array}{l}\text { RPF-Cuyabeno, } \\
\text { Sucumbíos, Ecuador }\end{array}$ & 13 & $\begin{array}{l}\text { EU47 } \\
7061\end{array}$ & $\begin{array}{l}K X 76 \\
2226\end{array}$ & $\begin{array}{l}\text { KX76 } \\
2197\end{array}$ & $\begin{array}{l}K \times 76 \\
2182\end{array}$ & $\begin{array}{l}K X 76 \\
2130\end{array}$ & $\begin{array}{l}K X 76 \\
2156\end{array}$ & $\begin{array}{l}\text { SAMN06 } \\
827884\end{array}$ \\
\hline $\begin{array}{l}\text { G. } \\
\text { humera } \\
\text { lis }\end{array}$ & $\begin{array}{l}\text { LSUMZ } \\
12639\end{array}$ & $\begin{array}{l}\text { RPF-Cuyabeno, } \\
\text { Sucumbíos, Ecuador }\end{array}$ & 13 & $\begin{array}{l}\text { EF56 } \\
4030\end{array}$ & $\begin{array}{l}K X 76 \\
2227\end{array}$ & $\begin{array}{l}\text { KX76 } \\
2198\end{array}$ & $\begin{array}{l}\text { EF56 } \\
4084\end{array}$ & $\begin{array}{l}K X 76 \\
2131\end{array}$ & $\begin{array}{l}K X 76 \\
2157\end{array}$ & $\begin{array}{l}\text { SAMN06 } \\
827885\end{array}$ \\
\hline $\begin{array}{l}\text { G. } \\
\text { antillen } \\
\text { sis }\end{array}$ & $\begin{array}{l}\text { YPM17 } \\
581\end{array}$ & $\begin{array}{l}\text { Westpunt Bay Beach, } \\
\text { Curaçao }\end{array}$ & N/A. & $\begin{array}{l}K \times 76 \\
2123\end{array}$ & $\begin{array}{l}K X 76 \\
2248\end{array}$ & $\begin{array}{l}K \times 76 \\
2216\end{array}$ & $\begin{array}{l}\text { KX76 } \\
2191\end{array}$ & $\begin{array}{l}K X 76 \\
2149\end{array}$ & $\begin{array}{l}K X 76 \\
2176\end{array}$ & N/A. \\
\hline $\begin{array}{l}\text { G. } \\
\text { antillen } \\
\text { sis }\end{array}$ & $\begin{array}{l}\text { YPM17 } \\
582\end{array}$ & $\begin{array}{l}\text { Westpunt Bay Beach, } \\
\text { Curaçao }\end{array}$ & N/A. & $\begin{array}{l}\text { KX76 } \\
2124\end{array}$ & $\begin{array}{l}K \times 76 \\
2249\end{array}$ & $\begin{array}{l}\text { KX76 } \\
2217\end{array}$ & $\begin{array}{l}K X 76 \\
2192\end{array}$ & $\begin{array}{l}K X 76 \\
2150\end{array}$ & $\begin{array}{l}\text { KX76 } \\
2177\end{array}$ & N/A. \\
\hline $\begin{array}{l}\text { G. } \\
\text { antillen } \\
\text { sis }\end{array}$ & $\begin{array}{l}\text { YPM17 } \\
583\end{array}$ & $\begin{array}{l}\text { Westpunt Bay Beach, } \\
\text { Curaçao }\end{array}$ & N/A. & $\begin{array}{l}K X 76 \\
2125\end{array}$ & $\begin{array}{l}\text { KP64 } \\
0636\end{array}$ & $\begin{array}{l}\text { KP64 } \\
0630\end{array}$ & $\begin{array}{l}\text { KP64 } \\
0623\end{array}$ & $\begin{array}{l}K X 76 \\
2151\end{array}$ & $\begin{array}{l}K X 76 \\
2178\end{array}$ & N/A. \\
\hline
\end{tabular}

Supplementary data 8.

Supplementary Table 2. GenBank accessibility for StarBEAST2 analysis from Higham et al. (2017) and this study

\begin{tabular}{|c|c|c|c|c|c|c|c|c|}
\hline Species & $16 S$ & ND2 & ACM4 & RAG1 & RAG2 & CMOS & PTPN12 & PDC \\
\hline G. ferrugineus & $\begin{array}{l}\text { KX76211 } \\
3\end{array}$ & $\begin{array}{l}\text { KX76223 } \\
6\end{array}$ & -- & $\begin{array}{l}\text { KX76220 } \\
7\end{array}$ & -- & $\begin{array}{l}\text { KX76225 } \\
7\end{array}$ & $\begin{array}{l}\text { KX76214 } \\
1\end{array}$ & -- \\
\hline G. ferrugineus & $\begin{array}{l}\text { KX76211 } \\
9\end{array}$ & $\begin{array}{l}\text { KX76224 } \\
2\end{array}$ & -- & $\begin{array}{l}\text { KX76221 } \\
2\end{array}$ & -- & $\begin{array}{l}\text { KX76225 } \\
3\end{array}$ & $\begin{array}{l}\text { KX76214 } \\
6\end{array}$ & -- \\
\hline G. ferrugineus & $\begin{array}{l}\text { KX76212 } \\
0\end{array}$ & $\begin{array}{l}\text { KX76224 } \\
3\end{array}$ & -- & $\begin{array}{l}\text { KX76221 } \\
3\end{array}$ & -- & $\begin{array}{l}\text { KX76225 } \\
2\end{array}$ & $\begin{array}{l}\text { KX76214 } \\
7\end{array}$ & -- \\
\hline
\end{tabular}




\begin{tabular}{|c|c|c|c|c|c|c|c|c|}
\hline G. humeralis_East & $\begin{array}{l}\text { EU47705 } \\
7\end{array}$ & $\begin{array}{l}\text { KX76221 } \\
8\end{array}$ & $\begin{array}{l}\text { EF56405 } \\
7\end{array}$ & $\begin{array}{l}\text { KX76219 } \\
3\end{array}$ & $\begin{array}{l}\text { EF56410 } \\
9\end{array}$ & $\begin{array}{l}\text { KX76217 } \\
9\end{array}$ & $\begin{array}{l}\text { KX76212 } \\
6\end{array}$ & -- \\
\hline G. humeralis_East & $\begin{array}{l}\text { EF56404 } \\
0\end{array}$ & $\begin{array}{l}\text { KX76222 } \\
0\end{array}$ & $\begin{array}{l}\text { EF56406 } \\
6\end{array}$ & -- & $\begin{array}{l}\text { EF56411 } \\
8\end{array}$ & $\begin{array}{l}\text { EF56409 } \\
2\end{array}$ & -- & -- \\
\hline G. humeralis_East & $\begin{array}{l}\text { EF56403 } \\
1\end{array}$ & $\begin{array}{l}\text { KX76222 } \\
4\end{array}$ & $\begin{array}{l}\text { EF56405 } \\
9\end{array}$ & $\begin{array}{l}\text { KX76219 } \\
6\end{array}$ & $\begin{array}{l}\text { EF56411 } \\
1\end{array}$ & $\begin{array}{l}\text { EF56408 } \\
5\end{array}$ & $\begin{array}{l}\text { KX76212 } \\
9\end{array}$ & -- \\
\hline $\begin{array}{l}\text { G. } \\
\text { humeralis_West }\end{array}$ & $\begin{array}{l}\text { EF56402 } \\
8\end{array}$ & $\begin{array}{l}\text { KX76224 } \\
6\end{array}$ & $\begin{array}{l}\text { EF56405 } \\
6\end{array}$ & $\begin{array}{l}\text { KX76221 } \\
5\end{array}$ & $\begin{array}{l}\text { EF56410 } \\
8\end{array}$ & $\begin{array}{l}\text { EF56408 } \\
2\end{array}$ & $\begin{array}{l}\text { KX76214 } \\
0\end{array}$ & -- \\
\hline $\begin{array}{l}\text { G. } \\
\text { humeralis_West }\end{array}$ & $\begin{array}{l}\text { EF56401 } \\
3\end{array}$ & $\begin{array}{l}J X 04136 \\
1\end{array}$ & $\begin{array}{l}\text { EF53487 } \\
9\end{array}$ & $\begin{array}{l}\text { EF53479 } \\
6\end{array}$ & $\begin{array}{l}\text { EF53496 } \\
4\end{array}$ & $\begin{array}{l}\text { EF53492 } \\
2\end{array}$ & $\begin{array}{l}\text { JF41686 } \\
0\end{array}$ & -- \\
\hline G. antillensis & $\begin{array}{l}\text { KX76212 } \\
3\end{array}$ & $\begin{array}{l}\text { KX76224 } \\
7\end{array}$ & -- & $\begin{array}{l}\text { KX76221 } \\
6\end{array}$ & -- & $\begin{array}{l}\text { KX76219 } \\
1\end{array}$ & $\begin{array}{l}\text { KX76214 } \\
9\end{array}$ & -- \\
\hline G. antillensis & $\begin{array}{l}\text { KX76212 } \\
4\end{array}$ & $\begin{array}{l}\text { KX76224 } \\
8\end{array}$ & -- & $\begin{array}{l}\text { KX76221 } \\
7\end{array}$ & -- & $\begin{array}{l}\text { KX76219 } \\
2\end{array}$ & $\begin{array}{l}\text { KX76215 } \\
0\end{array}$ & -- \\
\hline G. antillensis & $\begin{array}{l}\text { KX76212 } \\
5\end{array}$ & $\begin{array}{l}\text { KP64063 } \\
6\end{array}$ & $\begin{array}{l}\text { KP64062 } \\
7\end{array}$ & $\begin{array}{l}\text { KP64063 } \\
0\end{array}$ & $\begin{array}{l}\text { KP64062 } \\
5\end{array}$ & $\begin{array}{l}\text { KP64062 } \\
3\end{array}$ & $\begin{array}{l}\text { KX76215 } \\
1\end{array}$ & -- \\
\hline G. eladioi & $\begin{array}{l}\mathrm{HQ} 4261 \\
95\end{array}$ & -- & $\begin{array}{l}\text { EF56405 } \\
5\end{array}$ & $\begin{array}{l}\mathrm{HQ} 4262 \\
83\end{array}$ & $\begin{array}{l}\text { EF56410 } \\
7\end{array}$ & $\begin{array}{l}\text { EF56408 } \\
1\end{array}$ & $\begin{array}{l}J F 41685 \\
9\end{array}$ & $\begin{array}{l}\mathrm{HQ} 4261 \\
95\end{array}$ \\
\hline G. hasemani & $\begin{array}{l}\text { EF56401 } \\
5\end{array}$ & $\begin{array}{l}\text { KT11956 } \\
9\end{array}$ & $\begin{array}{l}\text { EF53487 } \\
8\end{array}$ & -- & $\begin{array}{l}\text { EF53496 } \\
3\end{array}$ & $\begin{array}{l}\text { EF53492 } \\
1\end{array}$ & -- & $\begin{array}{l}\text { EF53483 } \\
7\end{array}$ \\
\hline G. albogularis & $\begin{array}{l}\text { EF56402 } \\
0\end{array}$ & $\begin{array}{l}J X 04135 \\
4\end{array}$ & $\begin{array}{l}\text { EF53488 } \\
0\end{array}$ & $\begin{array}{l}\text { EF53479 } \\
7\end{array}$ & $\begin{array}{l}\text { EF53496 } \\
5\end{array}$ & $\begin{array}{l}\text { EF53492 } \\
3\end{array}$ & $\begin{array}{l}J F 41685 \\
4\end{array}$ & $\begin{array}{l}\text { EF53483 } \\
9\end{array}$ \\
\hline $\begin{array}{l}\text { G. } \\
\text { alexandermendesi }\end{array}$ & $\begin{array}{l}\text { EF56402 } \\
6\end{array}$ & $\begin{array}{l}J \times 04135 \\
5\end{array}$ & $\begin{array}{l}\text { EF53488 } \\
1\end{array}$ & $\begin{array}{l}\text { EF53479 } \\
8\end{array}$ & $\begin{array}{l}\text { EF53496 } \\
6\end{array}$ & $\begin{array}{l}\text { EF53492 } \\
4\end{array}$ & -- & $\begin{array}{l}\text { EF53484 } \\
0\end{array}$ \\
\hline G. annularis & $\begin{array}{l}\text { EF56403 } \\
7\end{array}$ & $\begin{array}{l}\text { JX04135 } \\
6\end{array}$ & $\begin{array}{l}\text { EF53487 } \\
6\end{array}$ & $\begin{array}{l}\text { EF53479 } \\
4\end{array}$ & $\begin{array}{l}\text { EF53496 } \\
1\end{array}$ & $\begin{array}{l}\text { EF53491 } \\
9\end{array}$ & $\begin{array}{l}\text { JF41685 } \\
5\end{array}$ & $\begin{array}{l}\text { EF53483 } \\
5\end{array}$ \\
\hline G. caudiscutatus & $\begin{array}{l}\text { EF56401 } \\
1\end{array}$ & $\begin{array}{l}\mathrm{JX} 04135 \\
7\end{array}$ & $\begin{array}{l}\text { EF53487 } \\
7\end{array}$ & $\begin{array}{l}\text { EF53479 } \\
5\end{array}$ & $\begin{array}{l}\text { EF53496 } \\
2\end{array}$ & $\begin{array}{l}\text { EF53492 } \\
0\end{array}$ & $\begin{array}{l}\text { JF41685 } \\
6\end{array}$ & $\begin{array}{l}\text { EF53483 } \\
6\end{array}$ \\
\hline G. $C$ & $\begin{array}{l}\text { EF56403 } \\
5\end{array}$ & $\begin{array}{l}\text { JX04135 } \\
8\end{array}$ & $\begin{array}{l}\text { EF56406 } \\
2\end{array}$ & JF416914 & $\begin{array}{l}\text { EF56411 } \\
4\end{array}$ & $\begin{array}{l}\text { EF56408 } \\
8\end{array}$ & $\begin{array}{l}\text { JF41685 } \\
7\end{array}$ & $\begin{array}{l}\mathrm{HQ} 4261 \\
93\end{array}$ \\
\hline G. concinnatus & $\begin{array}{l}\text { EF56401 } \\
2\end{array}$ & $\begin{array}{l}\text { JX04135 } \\
9\end{array}$ & $\begin{array}{l}\text { EF56404 } \\
4\end{array}$ & $\begin{array}{l}\mathrm{HQ} 4262 \\
82\end{array}$ & $\begin{array}{l}\text { EF56409 } \\
6\end{array}$ & $\begin{array}{l}\text { EF56407 } \\
0\end{array}$ & $\begin{array}{l}\text { JF41685 } \\
8\end{array}$ & $\begin{array}{l}\text { HQ4261 } \\
94\end{array}$ \\
\hline G. daudini & $\begin{array}{l}\text { EF56403 } \\
4\end{array}$ & $\begin{array}{l}\mathrm{JX04136} \\
0\end{array}$ & $\begin{array}{l}\text { EF53487 } \\
5\end{array}$ & $\begin{array}{l}\text { EF53479 } \\
3\end{array}$ & $\begin{array}{l}\text { EF53496 } \\
0\end{array}$ & $\begin{array}{l}\text { EF53491 } \\
8\end{array}$ & -- & $\begin{array}{l}\text { EF53483 } \\
4\end{array}$ \\
\hline G. ocellatus & $\begin{array}{l}\text { EF56401 } \\
4\end{array}$ & $\begin{array}{l}\text { JX04136 } \\
2\end{array}$ & $\begin{array}{l}\text { EF56404 } \\
6\end{array}$ & $\begin{array}{l}\mathrm{HQ} 4262 \\
84\end{array}$ & $\begin{array}{l}\text { EF56409 } \\
8\end{array}$ & $\begin{array}{l}\text { EF56407 } \\
2\end{array}$ & -- & $\begin{array}{l}\mathrm{HQ} 4261 \\
96\end{array}$ \\
\hline G. vit & $\begin{array}{l}\text { EF56403 } \\
2\end{array}$ & $\begin{array}{l}\text { JX04136 } \\
3\end{array}$ & $\begin{array}{l}\text { EF56406 } \\
0\end{array}$ & $\begin{array}{l}\mathrm{HQ} 4262 \\
85\end{array}$ & $\begin{array}{l}\text { EF56411 } \\
2\end{array}$ & $\begin{array}{l}\text { EF56408 } \\
6\end{array}$ & -- & $\begin{array}{l}\text { KT11956 } \\
8\end{array}$ \\
\hline L. festae & $\begin{array}{l}\text { EF56400 } \\
7\end{array}$ & -- & $\begin{array}{l}\text { EF56404 } \\
2\end{array}$ & $\begin{array}{l}\mathrm{HQ} 4262 \\
97\end{array}$ & $\begin{array}{l}\text { EF56409 } \\
4\end{array}$ & $\begin{array}{l}\text { EF56406 } \\
8\end{array}$ & $\begin{array}{l}\text { JF41686 } \\
2\end{array}$ & $\begin{array}{l}\mathrm{HQ} 4262 \\
08\end{array}$ \\
\hline L. sp. & $\begin{array}{l}\text { EF56400 } \\
8\end{array}$ & $\begin{array}{l}\text { JX04137 } \\
5\end{array}$ & $\begin{array}{l}\text { EF53487 } \\
1\end{array}$ & $\begin{array}{l}\text { EF53478 } \\
9\end{array}$ & $\begin{array}{l}\text { EF53495 } \\
6\end{array}$ & $\begin{array}{l}\text { EF53491 } \\
4\end{array}$ & $\begin{array}{l}\text { JF41686 } \\
1\end{array}$ & $\begin{array}{l}\text { EF53483 } \\
0\end{array}$ \\
\hline L. $x$ & $\begin{array}{l}\text { EF56400 } \\
9\end{array}$ & $\begin{array}{l}\text { JX04137 } \\
6\end{array}$ & $\begin{array}{l}\text { EF53487 } \\
2\end{array}$ & $\begin{array}{l}\text { EF53479 } \\
0\end{array}$ & $\begin{array}{l}\text { EF53495 } \\
7\end{array}$ & $\begin{array}{l}\text { EF53491 } \\
5\end{array}$ & $\begin{array}{l}\text { JF41686 } \\
3\end{array}$ & $\begin{array}{l}\text { EF53483 } \\
1\end{array}$ \\
\hline
\end{tabular}

Supplementary data 9.

Supplementary Table 3. Within-group measures of genetic diversity using mtDNA. Within-group genetic distances for each cluster ( $p$-distances) with standard error (S.E.) calculated using 500 bootstrap replicates in 
MEGA7 (Kumar et al. 2016). Nucleotide diversity $(\pi)$ for each cluster and standard deviations (sd), calculated using DNAsp (Librado \& Rozas, 2009); including 99\% confidence intervals ( $\pi \pm 3 * s d$ ).

\begin{tabular}{|c|c|c|c|c|c|}
\hline $\begin{array}{l}\text { Geographic } \\
\text { Cluster }\end{array}$ & $\begin{array}{l}\text { within-group p- } \\
\text { distance }\end{array}$ & S.E. & pi & sd & $\begin{array}{l}\text { pi }( \pm) 3^{*} \text { sd } \\
* * *\end{array}$ \\
\hline G. humeralis East & 0.0578 & $\begin{array}{l} \pm 0.00 \\
45\end{array}$ & 0.05811 & $\begin{array}{l}0.003 \\
2\end{array}$ & $\begin{array}{l}0.04851- \\
0.06771\end{array}$ \\
\hline $\begin{array}{l}\text { G. humeralis } \\
\text { West }\end{array}$ & 0.0296 & $\begin{array}{l} \pm 0.00 \\
33\end{array}$ & 0.02761 & $\begin{array}{l}0.005 \\
14\end{array}$ & $\begin{array}{l}0.01219- \\
0.04303\end{array}$ \\
\hline $\begin{array}{l}\text { G. humeralis } \\
\text { Trinidad }\end{array}$ & 0.0026 & $\begin{array}{l} \pm 0.00 \\
12\end{array}$ & 0.00284 & $\begin{array}{l}0.000 \\
32\end{array}$ & $\begin{array}{l}0.00188- \\
0.0038\end{array}$ \\
\hline \multirow[t]{2}{*}{ G. antillensis } & 0.0074 & $\begin{array}{l} \pm 0.00 \\
23\end{array}$ & 0.0071 & $\begin{array}{l}0.002 \\
06\end{array}$ & $\begin{array}{l}0.00092- \\
0.01328\end{array}$ \\
\hline & $\begin{array}{l}\text { MEGA7 (Kumar et al. } \\
\text { 2016) }\end{array}$ & & $\begin{array}{l}\text { DNAsp v5.0 (Librado \& } \\
\text { Rozas, 2009) }\end{array}$ & & \\
\hline
\end{tabular}

\section{References}

Ahrens et al., 2016 D. Ahrens, T. Fujisawa, H. Krammer, J. Eberle, S. Fabrizi, A.Vogler Rarity and incomplete sampling in DNA-based species delimitation Syst. Biol., 65 (3) (2016), pp. 478494, 10.1093/sysbio/syw002

Alexander et al., 2017 A. Alexander, Y. Su, C. Oliveros, K. Olson, S. Travers, R.Brown Genomic data reveals potential for hybridization, introgression, and incomplete lineage sorting to confound phylogenetic relationships in an adaptive radiation of narrow-mouth frogs Evolution, 71 (2) (2017), pp. 475 488, 10.1111/evo.13133

Angulo and Icochea, 2010 A. Angulo, J. Icochea Cryptic species complexes, widespread species and conservation: lessons from Amazonian frogs of the Leptodactylus marmoratus group (Anura: Leptodactylidae)

Syst. Biodivers., 8 (2010), pp. 357-370

Antonelli et al., 2011 A. Antonelli, A. Quijada-Mascareñas, A. Crawford, J. Bates, P.M. Velazco, W. Wüster Molecular studies and phylogeography of amazonian tetrapods and their relation to geological and climatic models.Ch. 24: Amazonia: landscape and species Evolution (2011), pp. 386404, 10.1002/9781444306408

Avila-Pires, 1995 T. Avila-Pires Lizards of Brazilian Amazonia (Reptilia: Squamata) Zoologische Verhandelingen, 299 (1) (1995)

Avila-Pires et al., 2012 T. Avila-Pires, D. Mulcahy, F. Werneck, J. Sites Phylogeography of the teiid lizard Kentropyx calcarata and the sphaerodactylid Gonatodes humeralis (Reptilia: Squamata): testing a geological scenario for the lower Amazon-Tocantins basins, Amazonia, Brazil Herpetologica, 68 (2) (2012), pp. 272-287, 10.1655/herpetologica-d-11-00021.1

Barley et al., 2018 A. Barley, J. Brown, R. Thomson Impact of model violations on the inference of species boundaries under the multispecies coalescent Syst. Biol., 67 (2) (2018), pp. 269$284,10.1093 /$ sysbio/syx077

Barraclough et al., 2009 T. Barraclough, M. Hughes, N. Ashford-Hodges, T.Fujisawa Inferring evolutionarily significant units of bacterial diversity from broad environmental surveys of single-locus data Biol. Lett., 5 (3) (2009), pp. 425-428, 10.1098/rsbl.2009.0091

Beck and Kitching, $2007 \mathrm{~J}$. Beck, I. Kitching Correlates of range size and dispersal ability: a comparative analysis of sphingid moths from the Indo-Australian tropics

Glob. Ecol. Biogeogr., 16 (3) (2007), pp. 341-349, 10.1111/j.1466-8238.2007.00289.x

Beheregaray, $2008 \mathrm{~L}$. Beheregaray Twenty years of phylogeography: the state of the field and the challenges for the Southern Hemisphere Mol. Ecol., 17 (2008), pp. 3754-3774

Bergmann and Russell, 2007 P. Bergmann, A. Russell Systematics and biogeography of the widespread Neotropical gekkonid genus Thecadactylus (Squamata), with the description of a new cryptic species 
Zool. J. Linn. Soc., 149 (3) (2007), pp. 339-370, 10.1111/j.1096-3642.2007.00251.x

Botov et al., 2015 A. Botov, T. Phung, T. Nguyen, A. Bauer, I. Brennan, T. Ziegler A new species of Dixonius (Squamata: Gekkonidae) from Phu Quy Island, Vietnam Zootaxa, 4040 (1) (2015), pp. 4858, 10.11646/zootaxa.4040.1.4

Boulenger, 1885 Boulenger, G., 1885. Catalogue of the Lizards in the British Museum (Nat. Hist.) I. Geckonidae, Eublepharidae, Uroplatidae, Pygopodidae, Agamidae. London. 450 pp.

Bouckaert et al., 2014 R. Bouckaert, J. Heled, D. Kuehnert, T. Vaughan, C. Wu, D.Xie, et al. BEAST 2: a software platform for Bayesian evolutionary analysis PLoS Comput. Biol., 10 (4) (2014), Article e1003537, 10.1371/journal.pcbi.1003537

Bryant et al., 2012 D. Bryant, R. Bouckaert, J. Felsenstein, N. Rosenberg, A.RoyChoudhury Inferring species trees directly from biallelic genetic markers: bypassing gene trees in a full coalescent analysis Mol. Biol. Evol., 29 (8) (2012), pp. 1917-1932, 10.1093/molbev/mss086

Burbrink et al., 2011 F.T. Burbrink, H. Yao, M. Ingrasci, R.W. Bryson, T.J. Guiher, S. Ruane Speciation at the mogollon rim in the Arizona mountain kingsnake (Lampropeltis pyromelana) Mol. Phylogenet.

Evol., 60 (3) (2011), pp. 445-454, 10.1016/i.ympev.2011.05.009

Burggren, 1992 W. Burggren Respiration and circulation in land crabs: novel variations on the marine design Am. Zool., 32 (1992), pp. 417-427, 10.1093/icb/32.3.417

Burt \& Burt, 1933 Burt \& Burt A preliminary checklist of the lizards of South America Trans. Acad. Sci. St Louis., 28 (1) (1933), pp. 1-104

Bush and Oliveira, 2006 M. Bush, P. Oliveira The rise and fall of the Refugial Hypothesis of Amazonian speciation: a paleoecological perspective Biota Neotrop., 6 (1) (2006), 10.1590/s1676$\underline{06032006000100002}$

Camargo et al., 2006 A. Camargo, R. De Sa, W. Heyer Phylogenetic analyses of mtDNA sequences reveal three cryptic lineages in the widespread neotropical frog Leptodactylus fuscus (Schneider, 1799) (Anura, Leptodactylidae) Biol. J. Linn. Soc., 87 (2) (2006), pp. 325-341

Camargo et al., 2009 A. Camargo, W. Heyer, R. de Sá Phylogeography of the frog Leptodactylus validus (Amphibia: Anura): patterns and timing of colonization events in the Lesser Antilles Mol. Phylogenet. Evol., 53 (2) (2009), pp. 571-579, 10.1016/i.ympev.2009.07.004

Caminer et al., 2017 M. Caminer, B. Milá, M. Jansen, A. Fouquet, P.J. Venegas, G.Chávez, S. Ron Systematics of the Dendropsophus leucophyllatus species complex (Anura: Hylidae): cryptic diversity and the description of two new species PLOS ONE, 12 (3) (2017), Article e0171785, 10.1371/journal.pone.0171785 doi:10.1016/i.tree.2015.11.004

Cann et al., 1987 R. Cann, M. Stoneking, A. Wilson Mitochondrial DNA and human evolution Nature, 325 (1987), pp. 31-36, 10.1038/325031a0 Carvalho et al., 2008

Carvalho et al., 2008 E. Carvalho Jr., A. Lima, W. Magnusson, A. Albernaz Long-term effect of forest fragmentation on the Amazonian gekkonid lizards, Coleodactylus amazonicus and Gonatodes humeralis Austral Ecol., 33 (6) (2008), pp. 723-729, 10.1111/i.1442-9993.2008.01840.x

Casillas and Barbadilla, 2017 S. Casillas, A. Barbadilla Molecular population genetics Genetics, 205 (3) (2017), pp. 1003-1035, 10.1534/genetics.116.196493

Catchen et al., 2011 J. Catchen, A. Amores, P. Hohenlohe, W. Cresko, J.Postlethwait Stacks: building and genotyping loci de novo from short-read sequences G3: Genes|Genomes|Genetics, 1 (3) (2011), pp. 171-182, 10.1534/g3.111.000240

Chek et al., 2001 A. Chek, S. Lougheed, J. Bogart, P. Boag Perception and history: molecular phylogeny of a diverse group of Neotropical frogs, the 30-chromosome Hyla (Anura: Hylidae) Mol. Phylogenet. Evol., 18 (3) (2001), pp. 370-385, 10.1006/mpev.2000.0889

Clarke et al., 2017a D. Clarke, P. York, M. Rasheed, T. Northfield Does biodiversity-ecosystem function literature neglect tropical ecosystems? Trends Ecol. Evol., 32 (5) (2017), pp. 320323, 10.1016/i.tree.2017.02.012

Clarke et al., 2017b D. Clarke, P. York, M. Rasheed, T. Northfield Identifying areas of need in tropical research: a reply to Stroud and Feeley Trends Ecol. Evol., 32 (9) (2017), p. 628, 10.1016/j.tree.2017.06.007 
Colston et al., 2013 T. Colston, F. Grazziotin, D. Shepard, L. Vitt, G. Colli, R. Henderson, F. Burbrink Molecular systematics and historical biogeography of tree boas (Corallusspp.) Mol. Phylogenet.

Evol., 66 (3) (2013), pp. 953-959, 10.1016/i.ympev.2012.11.027

Comeau, 1991 P. Comeau Geological events influencing natural vegetation in Trinidad Living World J. Trinidad \& Tobago Field Naturalist's Club, 100 (1991), pp. 29-38

Cope, 1864 Cope, E., 1864. Gonatodes ferrugineus. The Reptile Database in the Catalogue of Life in The Catalogue of Life Partnership: Catalogue of Life.

Cope, 1868 E. Cope An examination of the reptilia and Batrachia obtained by the orton expedition to Equador and the upper amazon, with notes on other species Proc. Acad. Nat. Sci. Philadelphia., 20 (1868), pp. 96-140

Costello et al., 2013 M. Costello, R. May, N. Stork Can we name Earth's species before they go extinct? Science, 339 (6118) (2013), pp. 413-416, 10.1126/science.1230318

Cracraft, $1985 \mathrm{~J}$. Cracraft Historical biogeography and patterns of differentiation within the South American avifauna: areas of endemism Am. Ornithol. Union Ornithol. Monogr., 36 (1985), pp. 49-84

D’angiolella et al., 2011 A. D'angiolella, T. Gamble, T. Avila-Pires, G. Colli, B.Noonan, L. Vitt Anolis chrysolepis Duméril and Bibron, 1837 (Squamata: Iguanidae), Revisited: molecular phylogeny and taxonomy of the Anolis chrysolepisspecies group Bull. Mus. Comp. Zool., 160 (2) (2011), pp. 3563, 10.3099/0027-4100-160.2.35

Da Silva and Patton, 1993 M. Da Silva, J. Patton Amazonian phylogeography: mtDNA sequence variation in arboreal echimyid rodents (Caviomorpha) Mol. Phylogenet. Evol., 2 (3) (1993), pp. 243-

255, 10.1006/mpev.1993.1023

De Oliveira et al., 2016 D. De Oliveira, V. de Carvalho, T. Hrbek Cryptic diversity in the lizard genus Plica (Squamata): phylogenetic diversity and Amazonian biogeography Zool Scripta, 45 (6) (2016), pp. 630-641, 10.1111/zsc.12172

De Queiroz, 2007 K. De Queiroz Species concepts and species delimitation Syst. Biol., 56 (6) (2007), pp. 879 $886,10.1080 / 10635150701701083$

Dexter and Chave, $2016 \mathrm{~K}$. Dexter, J. Chave Evolutionary patterns of range size, abundance and species richness in Amazonian angiosperm trees PeerJ, 4 (2016), Article e2402, 10.7717/peerj.2402

Díaz-Nieto et al., $2016 \mathrm{~J}$. Díaz-Nieto, S. Jansa, R. Voss DNA sequencing reveals unexpected recent diversity and an ancient dichotomy in the American marsupial genus Marmosops (Didelphidae: Thylamyini) Zool. J. Linn. Soc., 176 (4) (2016), pp. 914-940, 10.1111/zoj.12343

Diniz-Filho et al., 2013 J. Diniz-Filho, T. Soares, J. Lima, R. Dobrovolski, V.Landeiro, P. Telles, L. Bini Mantel test in population genetics Genet. Mol. Biol., 36 (4) (2013), pp. 475-485, 10.1590/S1415-47572013000400002

Ditchfield, $2000 \mathrm{~A}$. Ditchfield The comparative phylogeography of Neotropical mammals: patterns of intraspecific mitochondrial DNA variation among bats contrasted to nonvolant small mammals Mol. Ecol., 9 (9) (2000), pp. 1307-1318, 10.1046/j.1365-294x.2000.01013.x

Dixon and Soini, $1986 \mathrm{~J}$. Dixon, P. Soini The reptiles of the upper Amazon basin, Iquitos region, Peru, I-VII. Milwaukee Public Museum Amphibia-Reptilia, 9 (3) (1986), pp. 315-317, 10.1163/156853888x00422

Domingos et al., 2017 F. Domingos, G. Colli, A. Lemmon, E. Lemmon, L.Beheregaray In the shadows: phylogenomics and coalescent pecies delimitation unveil cryptic diversity in a Cerrado endemic lizard (Squamata: Tropidurus) Mol. Phylogenet. Evol., 107 (2017), pp. 455-465, 10.1016/j.ympev.2016.12.009

Donoso-Barros, 1968 R. Donoso-Barros The lizards of Venezuela (check list and key) Caribb J. Sci., 8 (3-

4) (1968), pp. 105-122

Dray and Dufour, 2007 S. Dray, A. Dufour The ade4 package: implementing the duality diagram for ecologists J. Stat. Soft., 22 (4) (2007), pp. 1-20, 10.18637/iss.v022.i04

Earl and vonHoldt, 2011 D. Earl, B. vonHoldt Structure Harvester: a website and program for visualizing STRUCTURE output and implementing the Evanno method Conserv. Genet. Res., 4 (2) (2011), pp. 359361, 10.1007/s12686-011-9548-7

Eaton, 2014 D. Eaton PyRAD: assembly of de novo RADseq loci for phylogenetic analyses Bioinformatics, 30 (13) (2014), pp. 1844-1849, 10.1093/bioinformatics/btu121 
Edgar, 2004 R. Edgar MUSCLE: multiple sequence alignment with high accuracy and high throughput Nucleic Acids Res., 32 (5) (2004), pp. 1792-1797, 10.1093/nar/gkh340

Edwards and Beerli, 2000 S. Edwards, P. Beerli Perspective: gene divergence, population divergence, and the variance in coalescence time in phylogeographic studies Evolution, 54 (6) (2000), pp. 1839-

1854, 10.1111/i.0014-3820.2000.tb01231.x

Eizirik et al., 2001 E. Eizirik, J. Kim, M. Menotti-Raymond, P. Crawshaw Jr., S.O'Brien, W. Johnson

Phylogeography, population history and conservation genetics of jaguars (Panthera onca, Mammalia,

Felidae) Mol. Ecol., 10 (1) (2001), pp. 65-79, 10.1046/i.1365-294x.2001.01144.x

Endler, 1977 J. Endler Geographic Variation, Speciation, and Clines Princeton University Press (1977)

Ersts, 2006 P. Ersts Geographic Distance Matrix Generator (Version 1.2.3) American Museum of Natural History, Center for Biodiversity and Conservation (2006)

Etter et al., 2011 P. Etter, S. Bassham, P. Hohenlohe, E. Johnson, W. Cresko SNP discovery and genotyping for evolutionary genetics using RAD sequencing V. Orgogozo, M. Rockman (Eds.), Molecular Methods for Evolutionary Genetics, Springer, New York (2011), pp. 157-178, 10.1007/978-1-61779-228-1 9

Evanno et al., 2005 G. Evanno, S. Regnaut, J. Goudet Detecting the number of clusters of individuals using the software structure: a simulation study Mol. Ecol., 14 (8) (2005), pp. 2611-2620, 10.1111/j.1365294x.2005.02553.x

Excoffier and Lischer, 2010 L. Excoffier, H. Lischer Arlequin suite ver 3.5: a new series of programs to perform population genetics analyses under Linux and Windows Mol. Ecol. Res., 10 (2010), pp. 564-

567, 10.1111/j.1755-0998.2010.02847.x

Farrell, 1998 B. Farrell "Inordinate fondness" explained: why are there so many beetles?

Science, 281 (5376) (1998), pp. 555-559, 10.1126/science.281.5376.555

Figueiredo et al., 2009 J. Figueiredo, C. Hoorn, P. van der Ven, E. Soares Late Miocene onset of the Amazon River and the Amazon deep-sea fan: evidence from the Foz do Amazonas Basin Geology, 37 (2009), pp. 619-622

Fouquet et al., 2007a A. Fouquet, M. Vences, M. Salducci, A. Meyer, C. Marty, M.Blanc, A. Gilles Revealing cryptic diversity using molecular phylogenetics and phylogeography in frogs of the Scinax ruber and Rhinella margaritiferaspecies groups Mol. Phylogenet. Evol., 43 (2) (2007), pp. 567582, 10.1016/i.ympev.2006.12.006

Fouquet et al., 2007b A. Fouquet, A. Gilles, M. Vences, C. Marty, M. Blanc, N.Gemmell Underestimation of species richness in neotropical frogs revealed by mtDNA analyses PLOS ONE, 2 (10) (2007), Article e1109, 10.1371/journal.pone.0001109

Fouquet et al., 2014 A. Fouquet, C. Cassini, C. Haddad, N. Pech, M. Rodrigues Species delimitation, patterns of diversification and historical biogeography of the Neotropical frog genus Adenomera (Anura, Leptodactylidae) J. Biogeogr., 41 (5) (2014), pp. 855-870

Fouquet et al., 2015 A. Fouquet, E. Courtois, D. Baudain, J. Lima, S. Souza, B.Noonan, M. Rodrigues The transriverine genetic structure of $\mathbf{2 8}$ Amazonian frog species is dependent on life history J. Trop. Ecol., 31 (4) (2015), pp. 361-373, 10.1017/s0266467415000206

Fu, 1997 Y. Fu Statistical tests of neutrality of mutations against population growth, hitchhiking and background selection Genetics., 147 (2) (1997), pp. 915-925 PMC1208208

Funk et al., 2012 W. Funk, M. Caminer, S. Ron High levels of cryptic species diversity uncovered in Amazonian frogs Proc. Roy. Soc. B: Biol. Sci., 279 (1734) (2012), pp. 1806-1814, 10.1098/rspb.2011.1653

Gamble et al., 2008 T. Gamble, A. Simons, G. Colli, L. Vitt Tertiary climate change and the diversification of the Amazonian gecko genus Gonatodes (Sphaerodactylidae, Squamata) Mol. Phylogenet.

Evol., 46 (1) (2008), pp. 269-277, 10.1016/i.ympev.2007.08.013

Gamble et al., 2011a T. Gamble, A. Bauer, G. Colli, E. Greenbaum, T. Jackman, L.Vitt, A. Simons Coming to America: multiple origins of New World geckos J. Evol. Biol., 24 (2) (2011), pp. 231-244

Gamble et al., 2011b T. Gamble, J. Daza, G. Colli, L. Vitt, A. Bauer A new genus of miniaturized and pug-nosed gecko from South America (Sphaerodactylidae: Gekkota) Zool. J. Linn. Soc., 163 (4) (2011), pp. 12441266, 10.1111/j.1096-3642.2011.00741.x 
Gamble et al., 2012a T. Gamble, G. Colli, M. Rodrigues, F. Werneck, A. Simons Phylogeny and cryptic diversity in geckos (Phyllopezus; Phyllodactylidae; Gekkota) from South America's open biomes Mol. Phylogenet. Evol., 62 (3) (2012), pp. 943-953, 10.1016/i.ympev.2011.11.033

Gamble et al., 2012b T. Gamble, E. Greenbaum, T. Jackman, A. Russell, A. Bauer Repeated origin and loss of adhesive toepads in geckos PLoS ONE, 7 (6) (2012), Article e39429, 10.1371/iournal.pone.0039429

Gamble et al., 2015 T. Gamble, E. Greenbaum, T. Jackman, A. Bauer Into the light: diurnality has evolved multiple times in geckos Biol. J. Linn. Soc., 115 (2015), pp. 896-910, 10.1111/bij.12536

Gamble et al., 2018 T. Gamble, E. McKenna, W. Meyer, S. Nielsen, B. Pinto, D.Scantlebury, T. Higham XX/XY sex chromosomes in the South American Dwarf Gecko (Gonatodes humeralis) J. Hered., 109 (2018), pp. $462-468$

Gazoni et al., 2018 T. Gazoni, C. Haddad, H. Narimatsu, D. Cabral-de-Mello, M.Lyra, P. Parise-Maltempi More sex chromosomes than autosomes in the Amazonian frog Leptodactylus pentadactylus

Gehara et al., 2014 M. Gehara, A. Crawford, V. Orrico, A. Rodríguez, S. Lötters, A. Fouquet, J. Köhler High levels of diversity uncovered in a widespread nominal taxon: continental phylogeography of the neotropical tree frog Dendropsophus minutus PLoS ONE, 9 (9) (2014),

Article e103958, 10.1371/journal.pone.0103958

Geurgas and Rodrigues, 2010 S. Geurgas, M. Rodrigues The hidden diversity of Coleodactylus

amazonicus (Sphaerodactylinae, Gekkota) revealed by molecular data Mol. Phylogenet.

Evol., 54 (2) (2010), pp. 583-593, 10.1016/j.ympev.2009.10.004

Glor et al., 2001 R. Glor, L. Vitt, A. Larson A molecular phylogenetic analysis of diversification in

Amazonian Anolislizards Mol. Ecol., 10 (11) (2001), pp. 2661-2668

Grismer et al., 2014a L. Grismer, C. Onn, S. Anuar, M. Muin Cyrts in the city: a new bent-toed Gecko

(Genus Cyrtodactylus) is the only endemic species of vertebrate from Batu Caves, Selangor, Peninsular Malaysia Zootaxa, 3774 (4) (2014), pp. 381-394, 10.11646/zootaxa.3774.4.6

Grismer et al., 2014b L. Grismer, P. Wood, S. Anuar, A. Riyanto, N. Ahmad, M.Muin, et al. Systematics and natural history of southeast Asian Rock Geckos (genus Cnemaspis Strauch, 1887) with descriptions of eight new species from Malaysia, Thailand, and Indonesia Zootaxa, 3880 (1) (2014), pp. 1-

147, 10.11646/zootaxa.3880.1.1

Grismer et al., 2017 L. Grismer, P. Wood, M. Kyaw Thura, T. Zin, E. Quah, M.Murdoch, et al. Phylogenetic taxonomy of Hemiphyllodactylus Bleeker, 1860 (Squamata: Gekkonidae) with descriptions of three new species from Myanmar J. Nat. Hist., 1-35 (2017), 10.1080/00222933.2017.1367045

Guayasamin et al., 2017 J. Guayasamin, C. Hutter, E. Tapia, J. Culebras, N.Peñafiel, R. Pyron, et al. Diversification of the rainfrog Pristimantis ornatissimus in the lowlands and Andean foothills of Ecuador PLOS

ONE, 12 (3) (2017), Article e0172615

Guichenot, 1855 Guichenot, A., 1855. Expédition dans les parties centrales de l'Amérique du Sud: de Rio de Janeiro à Lima, et de Lima au Para, vol. 1. P. Bertrand.

Gratton et al., 2015 P. Gratton, E. Trucchi, A. Trasatti, G. Riccarducci, S. Marta, G.Allegrucci, V. Sbordoni Testing classical species properties with contemporary data: how "bad species" in the brassy ringlets (Erebia tyndarus complex, Lepidoptera) turned good Syst. Biol., 65 (2) (2015), pp. 292

303, 10.1093/sysbio/syv087

Haffer, 1969 J. Haffer Speciation in Amazonian forest birds Science, 165 (1969), pp. 131-137

Haffer, $1997 \mathrm{~J}$. Haffer Alternative models of vertebrate speciation in Amazonia: an overview Biodiv.

Conserv., 6 (1997), pp. 451-476, 10.1023/A:1018320925954

Harvey et al., 2017 M. Harvey, A. Aleixo, C. Ribas, R. Brumfield Habitat association predicts genetic diversity and population divergence in Amazonian birds Am. Nat., 190 (5) (2017), pp. 631-648

Hedges and Conn, 2012 B. Hedges, C. Conn A new skink fauna from Caribbean islands (Squamata: Mabuyidae: Mabuyinae) Zootaxa, 3288 (2012), pp. 1-244

Hertz et al., 1993 P. Hertz, R. Huey, R. Stevenson Evaluating temperature regulation by field-active ectotherms: the fallacy of the inappropriate question Am. Nat., 142 (1993), pp. 796-818 
Hervas et al., 2016 Hervas, F., Elmer, K., Wake, D., Ron, S., 2016. Cryptic diversity and biogeography of South American salamanders. Pontificia Universidad Católica del Peru. Unpublished dissertation.

Hickerson et al., 2006 M. Hickerson, C. Meyer, C. Moritz DNA barcoding will often fail to discover new animal species over broad parameter space Syst. Biol., 55 (5) (2006), pp. 729-

739, 10.1080/10635150600969898

Higham et al., 2015 T. Higham, A. Birn-Jeffery, C. Collins, C. Hulsey, A. Russell Adaptive simplification and the evolution of gecko locomotion: morphological and biomechanical consequences of losing adhesion PNAS, 112 (2015), pp. 809-814, 10.1073/pnas.1418979112

Higham et al., 2016 T. Higham, S. Rogers, R. Langerhans, H. Jamniczky, G.Lauder, W. Stewart, et al. Speciation through the lens of biomechanics: locomotion, prey capture and reproductive isolation Proc. $R$. Soc. B, 283 (1838) (2016), p. 20161294, 10.1098/rspb.2016.1294

Higham et al., 2017 T. Higham, T. Gamble, A. Russell On the origin of adhesion in geckos: small morphological changes lead to a major biomechanical transition in the genus Gonatodes Biol. J. Linn. Soc., 120 (2017), pp. 503-517, 10.1111/bij.12897

Hoogmoed, 1973 M. Hoogmoed Notes on the Herpetofauna of Surinam IV: The Lizards and Amphisbaenians of Surinam, vol. 4, Springer Science \& Business Media(1973)

Hudson and Coyne, 2002 R. Hudson, J. Coyne Mathematical consequences of the genealogical species concept Evolution, 56 (8) (2002), pp. 1557-1565, 10.1554/0014-3820(2002) 056[1557:MCOTGS]2.0.CO;2

Hunt et al., $2001 \mathrm{~J}$. Hunt, E. Bermingham, R. Ricklefs Molecular systematics and biogeography of antillean thrashers, tremblers, and mockingbirds (Aves: Mimidae) Auk, 118 (1) (2001), pp. 35-55, 10.1642/00048038(2001) 118[0035:MSABOA]2.0.CO;2

Hunter, 1998 J. Hunter Key innovations and the ecology of macroevolution Trends Ecol. Evol., 13 (1) (1998), pp. 31-36, 10.1016/S0169-5347(97)01273-1

Hurlbert and White, 2007 A. Hurlbert, E. White Ecological correlates of geographical range occupancy in North American birds Glob. Ecol. Biogeogr., 16 (6) (2007), pp. 764-773, 10.1111/j.1466-8238.2007.00335.x

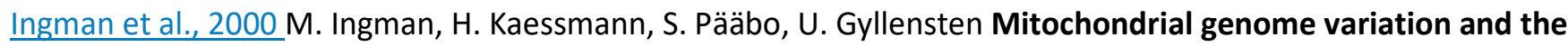
origin of modern humans Nature, 408 (6813) (2000), pp. 708-713, 10.1038/35047064

Jackman et al., 2008 T. Jackman, A. Bauer, E. Greenbaum, F. Glaw, M. Vences Molecular phylogenetic relationships among species of the Malagasy-Comoran gecko genus Paroedura (Squamata: Gekkonidae) Mol. Phylogenet. Evol., 46 (2008), pp. 74-81, 10.1016/j.ympev.2007.10.018

Jones, 2017 G. Jones Algorithmic improvements to species delimitation and phylogeny estimation under the multispecies coalescent J. Math. Biol., 74 (2017), pp. 447-467, 10.1007/s00285-016-1034-0

Jowers et al., 2008 M. Jowers, B. Cohen, J. Downie The cyprinodont fish Rivulus (Aplocheiloidei: Rivulidae) in Trinidad and Tobago: molecular evidence for marine dispersal, genetic isolation and local differentiation J. Zool. Syst. Evol. Res., 46 (1) (2008), pp. 48-55, 10.1111/j.1439-0469.2007.00422.x

Kapli et al., 2017 P. Kapli, S. Lutteropp, J. Zhang, K. Kobert, P. Pavlidis, A.Stamatakis, T. Flouri Multi-rate Poisson Tree Processes for single-locus species delimitation under maximum likelihood and Marcov Chain Monte Carlo Bioinformatics, 33 (11) (2017), pp. 1630-1638, 10.1093/bioinformatics/btx025

Kass and Raftery, 1995 R. Kass, A. Raftery Bayes factors J. Am. Stat. Assoc., 90 (430) (1995), pp. $773-$

795, 10.1080/01621459.1995.10476572

Kearse et al., 2012 M. Kearse, R. Moir, A. Wilson, S. Stones-Havas, M. Cheung, S.Sturrock, Buxton, et al.

Geneious Basic: an integrated and extendable desktop software platform for the organization and analysis of sequence data Bioinformatics, 28 (2012), pp. 1647-1649, 10.1093/bioinformatics/bts199

Kimura, 1983 M. Kimura The Neutral Theory of Molecular Evolution Cambridge University Press (1983)

Kluge, 1993 A. Kluge Gekkonoid Lizard Taxonomy International Gecko Society, San Diego, California,

U.S.A. (1993), pp. 1-245

Kluge, 1995 A. Kluge Cladistic relationships of sphaerodactyl lizards Am. Mus Novitates, 3139 (1995), pp. 1-23

Kluge, 2001 A. Kluge Gekkotan lizard taxonomy Hamadryad, 26 (2001), pp. 1-209 
Kopelman et al., 2015 N. Kopelman, J. Mayzel, M. Jakobsson, N. Rosenberg, I.Mayrose Clumpak: a program for identifying clustering modes and packaging population structure inferences across $\mathrm{K} \mathrm{Mol}$. Ecol. Res., 15 (5) (2015), pp. 1179-1191, 10.1111/1755-0998.12387

Kronauer et al., 2005 D. Kronauer, P. Bergmann, J. Mercera, A. Russell A phylogeographically distinct and deep divergence in the widespread Neotropical turnip-tailed gecko, Thecadactylus rapicauda Mol.

Phylogenet. Evol., 34 (2005), pp. 431-437, 10.1016/j.ympev.2004.10.009

Kumar et al., 2016 S. Kumar, G. Stecher, K. Tamura MEGA7: Molecular Evolutionary Genetics Analysis version

7.0 for bigger datasets Mol. Biol. Evol., 33 (2016), pp. 1870-1874, 10.1093/molbev/msw054

Latrubesse et al., 2010 E. Latrubesse, M. Cozzuol, S. da Silva-Caminha, C. Rigsby, M. Absy, C. Jaramillo The Late Miocene paleogeography of the Amazon Basin and the evolution of the Amazon River system EarthSci. Rev., 99 (3) (2010), pp. 99-124

Lawson et al., 2018 D. Lawson, L. van Dorp, D. Falush A tutorial on how not to over-interpret STRUCTURE and ADMIXTURE bar plots Nat. Comm. (2018), p. 9(1), 10.1038/s41467-018-05257

Leaché et al., 2014 A. Leaché, M. Fujita, Minin, R. Bouckaert Species delimitation using genome-wide SNP data Syst. Biol., 63 (2014), pp. 534-542, 10.1093/sysbio/syu018

Leaché et al., 2015 Leaché, A., Banbury, B., Felsenstein, J., de Oca, A., nieto-M., Stamatakis, A. (2015). Short tree, long tree, right tree, wrong tree: new acquisition bias corrections for inferring SNP phylogenies. Syst. Biol. 64(6), 1032-1047. https://doi.org/10.1093/sysbio/syv053.

Lemmon et al., 2012 A. Lemmon, S. Emme, E. Lemmon Anchored hybrid enrichment for massively high-

throughput phylogenomics Syst. Biol., 61 (2012), pp. 727-744, 10.1093/sysbio/sys049

Lessa et al., 2003 E. Lessa, J. Cook, J. Patton Genetic footprints of demographic expansion in North America, but not Amazonia, during the late Quaternary PNAS, 100 (18) (2003), pp. 10331-

0334, 10.1073/pnas.1730921100

Librado and Rozas, 2009 P. Librado, J. Rozas DnaSP v5: a software for comprehensive analysis of DNA

polymorphism data Bioinformatics, 25 (2009), pp. 1451-1452, 10.1093/bioinformatics/btp187

Liem, $1973 \mathrm{~K}$. Liem Evolutionary strategies and morphological innovations: cichlid pharyngeal jaws

Syst. Biol., 22 (4) (1973), pp. 425-441

Losos, 2011 J. Losos Lizards in an Evolutionary Tree: Ecology and Adaptive Radiation of Anoles

University of California Press (2011)

Lynch, $1979 \mathrm{~J}$. Lynch The amphibians of the lowland tropical forests W.E. Duellman (Ed.), The South American Herpetofauna: Its Origin, Evolution, and Dispersal, The Museum of Natural History, The University of Kansas, Lawrence, Kansas (1979), pp. 189-215

Macey et al., 1999 J. Macey, Y. Wang, N. Ananjeva, A. Larson, T. Papenfuss Vicariant patterns of fragmentation among gekkonid lizards of the genus Teratoscincus produced by the Indian collision: a molecular phylogenetic perspective and an area cladogram for central Asia Mol. Phylogenet. Evol., 12 (1999), pp. 320-332, 10.1006/mpev.1999.0641

Mantel, $1967 \mathrm{~N}$. Mantel The detection of disease clustering and a generalized regression approach Cancer Res., 27 (1967), pp. 209-220

McKay et al., 2013 B. McKay, H. Mays, Y. Wu, H. Li, C. Yao, I. Nishiumi, F. Zou An empirical comparison of character-based and coalescent-based approaches to species delimitation in a young avian complex Mol. Ecol., 22 (19) (2013), pp. 4943-4957

$10.1111 / \mathrm{mec}$

Meiri et al., 2017 S. Meiri, A. Bauer, A. Allison, F. Castro-Herrera, L. Chirio, G.Colli, et al. Extinct, obscure or imaginary: the lizard species with the smallest ranges Div. Dist. (2017) (in press)

Miller et al., 2010 M. Miller, W. Pfeiffer, T. Schwartz Creating the CIPRES Science Gateway for inference of large phylogenetic trees Proceedings of the Gateway Computing Environments Workshop (GCE), 14 Nov. 2010, New Orleans, LA (2010), pp. 1-8

Miralles and Carranza, 2010 A. Miralles, S. Carranza Systematics and biogeography of the Neotropical genus Mabuya, with special emphasis on the Amazonian skink Mabuya nigropunctata (Reptilia, Scincidae) Mol. Phylogenet. Evol., 54 (3) (2010), pp. 857-869, 10.1016/j.ympev.2009.10.016 
Moritz and Cicero, 2004 C. Moritz, C. Cicero DNA barcoding: promise and pitfalls PLoS Biol., 2 (10) (2004), Article e354, 10.1371/journal.pbio.0020354

Murphy, 1997 J. Murphy Amphibians and Reptiles of Trinidad and Tobago Krieger Publications (1997)

Murphy et al., 2017a J. Murphy, R. Lehtinen, S. Charles, D. Wasserman, T. Anton, P. Brennan Cryptic multicolored lizards in the Polychrus marmoratus Group (Squamata: Sauria: Polychrotidae) and the status of Leiolepis auduboniHallowell Amphib Reptile Conserv., 11 (1) (2017), pp. 1-16

Murphy et al., 2017b J. Murphy, T. Sierra, J. Downie, M. Jowers Toads, tall mountains and taxonomy: the Rhinella granulosa group (Amphibia: Anura: Bufonidae) on both sides of the Andes Salamandra, 53 (2) (2017), pp. 267-278

Nazareno et al., 2017a A. Nazareno, J. Bemmels, C. Dick, L. Lohmann Minimum sample sizes for population genomics: an empirical study from an Amazonian plant species Mol. Ecol. Res. (2017), 10.1111/17550998.1265t (in press)

Nazareno et al., 2017b A. Nazareno, C. Dick, L. Lohmann Wide but not impermeable: testing the riverine barrier hypothesis for an Amazonian plant species Mol. Ecol., 26 (14) (2017), pp. 3636-

3648, 10.1111/mec.14142

Nei and Li, 1979 M. Nei, W. Li Mathematical model for studying genetic variation in terms of restriction endonucleases

Noonan and Gaucher, 2005 B. Noonan, P. Gaucher Phylogeography and demography of Guianan harlequin toads (Atelopus): diversification within a refuge Mol. Ecol., 14 (10) (2005), pp. 3017-3031

Nunes et al., 2012 P. Nunes, A. Fouquet, F. Curcio, P. Kok, M. Rodrigues Cryptic species in Iphisa elegans Gray, 1851 (Squamata: Gymnophthalmidae) revealed by hemipenial morphology and molecular data Zool. J. Linn. Soc., 166 (2) (2012), pp. 361-376, 10.1111/j.1096-3642.2012.00846.x

Ogilvie and Leaché, 2016 Ogilvie, H., Leaché, A., 2016. Species delimitation in a SNAPP tutorial: bayes factor delimitation of species (*with genomic data; $\mathrm{BFD}$ ): a tutorial and working example.

Ogilvie et al., 2017 H. Ogilvie, R. Bouckaert, A. Drummond StarBEAST2 brings faster species tree inference and accurate estimates of substitution rates

Mol. Biol. Evol. (2017), 10.1093/molbev/msx126

Oliveira et al., 2017 U. Oliveira, M. Vasconcelos, A. Santos Biogeography of Amazon birds: rivers limit species composition, but not areas of endemism Sci. Rep., 7 (1) (2017), p. 2992, 10.1038/s41598-017-03098-w

Oliver et al., 2007 P. Oliver, M. Hutchinson, S. Cooper Phylogenetic relationships in the lizard genus Diplodactylus Gray and resurrection of Lucasium Wermuth (Gekkota, Diplodactylidae) Aust. J. Zool., 55 (3) (2007), pp. 197-210, 10.1071/ZO07008

Palumbi, 2001 S. Palumbi Humans as the world's greatest evolutionary force Science, 293 (5536) (2001), pp. 1786-1790, 10.1126/science.293.5536.1786

Parker, 1935 H. Parker The lizards of Trinidad Trop. Agric., 12 (3) (1935), pp. 65-70

Pepper et al., 2006 M. Pepper, P. Doughty, J. Keogh Molecular phylogeny and phylogeography of the Australian Diplodactylus stenodactylus (Gekkota; Reptilia) species-group based on mitochondrial and nuclear genes reveals an ancient split between Pilbara and non-Pilbara $D$. stenodactylus Mol. Phylogenet. Evol., 41 (3) (2006), pp. 539-555, 10.1016/j.ympev.2006.05.028

Pfeifer et al., 2014 B. Pfeifer, U. Wittelsbuerger, S. Ramos-Onsins, M. Lercher PopGenome: an efficient swiss army knife for population genomic Analyses in R Mol. Biol. Evol., 31 (7) (2014), pp. 19291936, 10.1093/molbev/msu136

Pons et al., 2006 J. Pons, T. Barraclough, J. Gomez-Zurita, A. Cardoso, D. Duran, S. Hazell, et al. Sequence-based species delimitation for the DNA taxonomy of undescribed insects Syst. Biol., 55 (4) (2006), pp. 595$609,10.1080 / 10635150600852011$

Portik et al., 2013 D. Portik, S.L. Travers, A.M. Bauer, W.R. Branch A new species of Lygodactylus (Squamata: Gekkonidae) endemic to Mount Namuli, an isolated 'sky island of northern Mozambique Zootaxa, 3710 (5) (2013), pp. 415-435, 10.11646/zootaxa.3710.5.2 
Prates et al., 2016 I. Prates, D. Rivera, M. Rodrigues, A. Carnaval A mid-Pleistocene rainforest corridor enabled synchronous invasions of the Atlantic Forest by Amazonian anole lizards Mol. Ecol., 25 (20) (2016), pp. 5174-5186, 10.1111/mec.13821

Pritchard et al., $2007 \mathrm{~J}$. Pritchard, M. Stephens, D. Falush Inference of population structure using multilocus genotype data: dominant markers and null alleles Mol. Ecol. Notes, 7 (4) (2007), pp. 574578, 10.1111/j.1471-8286.2007.01758.x

R Core Team, 2016 R Core Team, 2016. R: A Language and Environment for Statistical Computing. R Foundation for Statistical Computing, Vienna, Austria.

Rambaut et al., 2018 A. Rambaut, A. Drummond, D. Xie, G. Baele, M. Suchard Posterior summarization in Bayesian phylogenetics using Tracer 1.7. Syst. Biol., 67 (5) (2018), pp. 901-904, 10.1093/sysbio/syy032

Ree et al., 2005 R. Ree, B. Moore, C. Webb, M. Donoghue A likelihood framework for inferring the evolution of geographic range on phylogenetic trees Evolution, 59 (11) (2005), pp. 2299-2311, 10.1111/j.00143820.2005.tb00940.x

Ribeiro-Júnior, 2015 M. Ribeiro-Júnior Catalogue of distribution of lizards (Reptilia: Squamata) from the Brazilian Amazonia. II. Gekkonidae, Phyllodactylidae, Sphaerodactylidae Zootaxa, 3981 (1) (2015), p. 1, 10.11646/zootaxa.3981.1.1 Rivero-Blanco, 1979 C. Rivero-Blanco The Neotropical lizard genus Gonatodes Fitzinger (Sauria, Sphaerodactylinae). Unpublished dissertation Texas A\&M University (1979)

Roberto et al., 2014 I. Roberto, T. Pinto, Á. Schlickmann, A. Fraga From Amazonia to the semi-arid: the unexpected record of Gonatodes humeralis (Squamata: Sphaerodactylidae) for the Caatinga Biome Herpetol. Notes, 7 (2014), pp. 309-311

Rohland and Reich, 2012 N. Rohland, D. Reich Cost-effective, high-throughput DNA sequencing libraries for multiplexed target capture Genome Res., 22 (2012), pp. 939-946, 10.1101/gr.128124.111

Roll et al., 2017 U. Roll, A. Feldman, M. Novosolov, A. Allison, A. Bauer, R.Bernard, S. Meiri The global distribution of tetrapods reveals a need for targeted reptile conservation Nat. Ecol. Evol. (2017), 10.1038/s41559-017-0380-7

Roux, 1926 J. Roux Notes d’erpétologie sud-américaine Rev. Suisse Zool., 33 (4) (1926), pp. 291-299

Russell, 1979 A. Russell The origin of parachuting locomotion in gekkonid lizards (Reptilia: Gekkonidae) Zool. J. Linn. Soc., 65 (1979), pp. 233-249, 10.1111/i.1096-3642.1979.tb01093.x

Russell and Delaugerre, 2017 A. Russell, M. Delaugerre Left in the dust: differential effectiveness of the two alternative adhesive pad configurations in geckos (Reptilia: Gekkota) J. Zool., 301 (1) (2017), pp. 61$68,10.1111 /$ izo.12390

Russell et al., 2015 A. Russell, J. Baskerville, T. Gamble, T. Higham The evolution of digit form in Gonatodes (Gekkota: Sphaerodactylidae) and its bearing on the transition from frictional to adhesive contact in gekkotans J. Morph., 276 (11) (2015), pp. 1311-1332, 10.1002/jmor.20420

Schargel et al., 2010 W. Schargel, G. Rivas, R. Makowsky, J. Señaris, M. Natera, T.Barros Phylogenetic systematics of the genus Gonatodes (Squamata: Sphaerodactylidae) in the Guayana region, with description of a new species from Venezuela Syst. Biodiv., 8 (2010), pp. 321339, 10.1080/14772000.2010.504757

Shimodaira, $2002 \mathrm{H}$. Shimodaira An approximately unbiased test of phylogenetic tree selection Syst. Biol., 51 (3) (2002), pp. 492-508, 10.1080/10635150290069913

Shimodaira and Hasegawa, 1999 H. Shimodaira, M. Hasegawa Multiple comparisons of log-likelihoods with applications to phylogenetic inference Mol. Biol. Evol., 16 (8) (1999), pp. 11141116, 10.1093/oxfordjournals. molbev.a026201

Stamatakis, 2014 A. Stamatakis RAxML version 8: a tool for phylogenetic analysis and post-analysis of large phylogenies Bioinformatics, 30 (9) (2014), pp. 1312-1313, 10.1093/bioinformatics/btu033

Stephens et al., 2001 M. Stephens, N. Smith, P. Donnelly A new statistical method for haplotype reconstruction from population data Am. J. Hum. Genet., 68 (4) (2001), pp. 978-989, 10.1086/319501

Stroud and Losos, $2016 \mathrm{~J}$. Stroud, J. Losos Ecological opportunity and adaptive radiation Ann. Rev. Ecol. Evol., 47 (2016), pp. 507-532, 10.1146/annurev-ecolsys-121415-032254 
Stroud et al., $2017 \mathrm{~J}$. Stroud, K. Feeley Neglect of the tropics is widespread in ecology and evolution: a comment on Clarke et al. Trends Ecol. Evol., 32 (9) (2017), pp. 626-628, 10.1016/j.tree.2017.06.006

Sukumaran and Knowles, $2017 \mathrm{~J}$. Sukumaran, L. Knowles Multispecies coalescent delimits structure, not species PNAS, 114 (7) (2017), pp. 1607-1612, 10.1073/pnas.1607921114

Swofford, 2002 D. Swofford PAUP*: Phylogenetic Analysis Using Parsimony (* and Other Methods) Sunderland, MA (2002)

Tajima, 1989 F. Tajima Statistical method for testing the neutral mutation hypothesis by DNA polymorphism Genetics, 123 (3) (1989), pp. 585-595 PMC1203831

Thomason and Russell, $1986 \mathrm{~J}$. Thomason, A. Russell Mechanical factors in the evolution of the mammalian secondary palate: a theoretical analysis J. Morph., 189 (1986), pp. 199-213, 10.1002/jmor.1051890210

Turchetto-Zolet et al., 2013 A. Turchetto-Zolet, F. Pinheiro, F. Salgueiro, C.Palma-Silva Phylogeographical patterns shed light on evolutionary process in South America Mol. Ecol., 22 (5) (2013), pp. 1193$1213,10.1111 / \mathrm{mec} .12164$

Vanzolini, 1955 P. Vanzolini Sôbre Gonatodes varius (Auguste Duméril) com notas sôbre outras espécies do gênero (Sauria, Gekkonidae) Pap Avul Zool., 12 (1955), pp. 119-132

Vanzolini and Williams, 1981 P. Vanzolini, E. Williams The vanishing refuge: a mechanism for ecogeographic speciation Pap Avulsos de Zool., 34 (23) (1981), pp. 251-255

Vitt and Zani, 1996 L. Vitt, P. Zani Organization of a taxonomically diverse lizard assemblage in Amazonian Ecuador

Vitt et al., 1997 L. Vitt, P. Zani, A. Monteiro de Barros ecological variation among populations of the gekkonid lizard Gonatodes humeralis in the Amazon basin Copeia, 1 (1997), pp. 32-43, 10.2307/1447837

Vitt et al., 2000 L. Vitt, R. Souza, S. Sartorius, T. Avila-Pires, M. Espósito Comparative ecology of sympatric Gonatodes (Squamata: Gekkonidae) in the western Amazon of Brazil Copeia, 1 (2000), pp. 83-95, 10.1643/0045-8511(2000) 2000[0083:CEOSGS]2.0.CO;2

Wallace, $1852 \mathrm{~A}$. Wallace On the monkeys of the Amazon Zool. Soc. London (1852)

Webb, 1982 P. Webb Locomotor patterns in the evolution of actinopterygian fishes Am. Zool., 22 (1982), pp. 329-342, 10.1093/icb/22.2.329

Weir et al., 2015 J. Weir, M. Faccio, P. Pulido-Santacruz, A. Barrera-Guzmán, A.Aleixo Hybridization in headwater regions, and the role of rivers as drivers of speciation in Amazonian birds Evolution, 69 (7) (2015), pp. 1823-1834, 10.1111/evo.12696

Wellborn and Langerhans, 2014 G. Wellborn, R. Langerhans Ecological opportunity and the adaptive diversification of lineages Ecol. Evol., 5 (1) (2014), pp. 176-195, 10.1002/ece3.1347

Wermuth, $1965 \mathrm{H}$. Wermuth Liste der rexenten amphibian und reptilien. Gekkonidae, Pygopodidae, Xantusidae Das Tierreich., 80 (1965), pp. 1-246

Werneck et al., 2012 F. Werneck, T. Gamble, G. Colli, M. Rodrigues, J. Sites Jr. Deep diversification and longterm persistence in the South American 'dry diagonal': integrating continent-wide phylogeography and distribution modeling of geckos Evolution, 66 (10) (2012), pp. 3014-3034, 10.1111/i.1558-

5646.2012.01682.x

Wiens and Penkrot, 2002 J. Wiens, T. Penkrot Delimiting species using DNA and morphological variation and discordant species limits in spiny lizards (Sceloporus) Syst. Biol., 51 (1) (2002), pp. 69-

91, 10.1080/106351502753475880

Wynn and Heyer, 2001 A. Wynn, W. Heyer Do geographically widespread species of tropical amphibians exist? An estimate of genetic relatedness within the Neotropical frog Leptodactylus fuscus (Schneider 1799) (Anura Leptodactylidae) Trop Zool., 14 (2) (2001), pp. 255-285, 10.1080/03946975.2001.10531157

Zamudio and Greene, 1997 K. Zamudio, H. Greene Phylogeography of the bushmaster (Lachesis muta:

Viperidae): implications for Neotropical biogeography, systematics, and conservation Biol. J. Linn. Soc., 62 (3) (1997), pp. 421-442, 10.1111/j.1095-8312.1997.tb01634.x

Zink and Barrowclough, 2008 R. Zink, G. Barrowclough Mitochondrial DNA under siege in avian phylogeography Mol. Ecol., 17 (9) (2008), pp. 2107-2121, 10.1111/j.1365-294X.2008.03737.x 